\title{
ORCHIDS OF THE BLACK SEA COAST OF KRASNODARSKY KRAI (RUSSIA): CURRENT STATE, NEW RECORDS, CONSERVATION
}

\author{
Anton V. Popovich ${ }^{1}$, Elena A. Averyanova ${ }^{2}$, Lev M. Shagarov ${ }^{2,3}$ \\ ${ }^{1}$ Russian Geographical Society, Russia \\ e-mail:popovitch.antonio220386@yandex.ru \\ ${ }^{2} R U D N$ University, Russia \\ e-mail:drjoma2zimovnikova@gmail.com \\ ${ }^{3}$ Institute of Natural and Technical Systems, Russia \\ e-mail:lev049@mail.ru
}

Received: 09.05.2020. Revised: 12.07.2020. Accepted: 11.08.2020.

\begin{abstract}
The article provides a relevant nomenclature list of Orchidaceae on the Black Sea coast in Krasnodarsky Krai (Russia), with clarification of the taxonomic status of each taxon. Fifty-one taxa (41 species and eleven subspecies) are known in the study area; apart of them, there are ten hybrids. Of them, five taxa are not found anywhere else in Russia, including Cephalanthera epipactoides, Epipactis euxina (endemic), E. leptochila subsp. neglecta, E. pontica, and Serapias orientalis subsp. feldwegiana. Two taxa (Epipactis condensata and Ophrys mammosa subsp. caucasica) slightly exceed the boundaries of the study area. Data on the distribution, occurrence, and association of species with plant communities are provided. Most taxa are more or less represented in forest communities. Only eight species are confined to grassland communities and ecotonic habitats. For 19 taxa, favourable conditions seem to be in anthropogenically disturbed habitats, preferring clearings under power lines, sides of forest roads, deposits, hay meadows, and dendroparks. Data on new locations and the state of the most threatened orchid species on the Black Sea coast in Krasnodarsky Krai are presented. Three species, Anacamptis coriophora, Dactylorhiza incarnata and Epipactis palustris, seem to have disappeared in the study area, possibly due to human activity. The state of regional populations of ten taxa causes concerns about their conservation on the Black Sea coast in Krasnodarsky Krai. Seven taxa (Anacamptis laxiflora subsp. dielsiana, Cephalanthera epipactoides, Dactylorhiza viridis, Epipactis condensata, E. euxina, Neotinea ustulata, Ophrys apifera, and Himantoglossum comperianum) have a critical status. For these orchids, the risk of extinction is very high in the study area. The other three taxa can be described as endangered, namely Himantoglossum caprinum, Ophrys mammosa subsp. caucasica, Orchis militaris subsp. stevenii. The problems of orchid diversity conservation in the study area are identified. We are convinced that the most effective method of orchid conservation on the Black sea coast of Krasnodarsky Krai concerns the further developing of a Protected Area network, primarily through the creation of regional Protected Areas, including natural parks, nature monuments, municipal Protected Areas.
\end{abstract}

Key words: Caucasus, IUCN Red List category, nature conservation, nomenclature list, Orchidaceae, Protected Area, rare species, Red Data Book

\section{Introduction}

The Orchidaceae family is one of the largest families of angiosperm plants (more than 28000 species), probably giving the first place only to the Asteraceae family (Chase et al., 2003, 2015; Christenhusz \& Byng, 2016; Willis, 2017; Fay, 2018). Despite this, orchids are among the most vulnerable taxa of vascular plants. This is due to the peculiarities of their biology and ecology, anthropogenic impact on the environment, and global processes, causing a climate change (Gale et al., 2018). The southern part of European Russia is one of the richest Russian regions with 68 orchid taxa (Averyanov, 2006; Ivanov, 2019; Litvinskaya, 2019; Fateryga et al., 2019; Efimov, 2020). The most species-rich Russian region, regarding orchid diversity, is the Russian Far East with 71 taxa followed by Southern Russia (Efimov, 2020).

The biodiversity of the Black Sea coast of Krasnodarsky Krai is the most threatened due to the high anthropogenic pressure on natural ecosystems. About 3000000 people live here, and up to 16000000 people take vacations every year. In this region, the development of the touristic and recreational complex has predetermined active, not always justified and well-thought-out, anthropogenic interference with nature. They include changing the coastline, mining, construction of floodplain areas and the deformation of riverbeds, deforestation for ski resorts and the expansion of settlements, spontaneous recreation. All these represent a serious threat to many endemic taxa and taxa located at the edges of their ranges. In this area, most of these taxa have a regional or federal protection status (Red Data Book of Russian Federation, 2008; Litvinskaya, 2017).

The study area is formed by the Black Sea coast of Krasnodarsky Krai extended from the Black sea level to the altitude of $1000 \mathrm{~m}$ a.s.l. This area has a high index of orchid species diversity, represented by 
41 species, which is $80 \%$ of the orchid species known in Krasnodarsky Krai (Litvinskaya, 2019). This number is quite comparable with regions with a larger area, such as the Crimea with 45 species (Fateryga et al., 2019), Stavropolsky Krai with 25 species (Ivanov, 2019), Republic of Dagestan with 49 species (Efimov, 2020), Republic of Karachay-Cherkessia with 28 species (Zernov et al., 2015), Georgia with 53 taxa (Akhalkatsi et al., 2003), and Armenia with 43 species (Averyanov \& Nersesyan, 2001).

In recent years, in some of these regions, floristic lists were specified (Murtazaliev, 2009; Shilnikov, 2010; Yena, 2012; Zernov, 2013; Zernov et al., 2015; Ivanov, 2019; Popovich, 2019a; Litvinskaya, 2019). There, the volumes of the genera in the family Orchidaceae vary considerably, though many studies do not consider the current taxonomy of this family. The same situation can be seen in the regional Red Data Books and the Red Data Book of Russia. This may cause problems in protecting vulnerable and endangered orchid species (Flanagan et al., 2006; Hollingsworth et al., 2006; Vereecken et al., 2010; Fay, 2018) at regional, national, and international level. Thanks to current research, based on molecular-genetic methods, molecular-phylogenetic data has been accumulated. Taking into account the guiding criteria (Jin et al., 2017), they allow to determine the optimal boundaries of taxa within the family Orchidaceae (Jin et al., 2017; Bateman et al., 2017; Bateman \& Rudall, 2018; Zhou \& Jin, 2018).

This study aimed to present a nomenclature list of the family Orchidaceae in the Black Sea coast of Krasnodarsky Krai, taking into account the current taxonomic re-evaluation and nomenclature, to assess the vulnerability of taxa in the region and assess the current state of threatened orchid taxa.

\section{Methods}

The nomenclature list of orchids in the Black Sea coast of Krasnodarsky Krai is based on a number of publications on the flora of the study area (Lipsky, 1899; Grossheim, 1940; Averyanov, 2006; Zernov, 2006; Vakhrameeva et al., 2014; Ivanov, 2019; Litvinskaya, 2019), taking into account the latest taxonomic publications (Kuropatkin \& Efimov, 2014; Bateman et al., 2017; Bateman \& Rudall, 2018; Fateryga \& Fateryga, 2018; Fateryga et al., 2018a,b). Nomenclature combinations are listed in accordance with IPNI (2020).

The list of orchids shows the currently accepted names of taxa according to the «World Checklist of Orchidaceae» (Govaerts et al., 2020), basionym and synonyms which were indicated by other authors for the study area. A separate paragraph contains erroneous indications of orchid taxa in the study area.

The present publication contains information on orchids, obtained by the authors during field research in 2009-2019, covering the entire foothill and lowmountain parts of the Black Sea coast of Krasnodarsky Krai. The information provided in the publication is confirmed by material, stored in herbarium collections (MW, LE, and in the Sochi branch of the Russian Geographical Society), or by earlier publications of the authors, as well as photos posted on Plantarium (2020). Additional material was studied in the following herbaria: MW, LE, YALTA, CSSU, SIMF, SCR, MAY, KBAI, KW. All relevant floristic publications (Flerov \& Flerov, 1926; Maleev, 1931; Semagina, 1999; Zernov, 2000; Dubovic, 2005; Solodko et al., 2006; Zernov, 2013; Demina et al., 2015b; Suslova et al., 2015; Popovich, 2019a) and papers devoted to the study of orchids in the Northern and North-Western Caucasus (Timukhin, 2002, 2003; Ivanov \& Kovaleva, 2005; Chernovol, 2006; Solodko \& Makarova, 2011; Perebora, 2011) were taken into account. Photographic materials and indications in the electronic databases Plantarium (2020) and iNaturalist (2020) were analysed, too.

\section{Study area}

The study area includes the foothill and lowmountain part of the southern macroslope of the Main Caucasus range extending from the Black Sea water edge to the altitude of $1000 \mathrm{~m}$ a.s.l. The Black Sea coast of Krasnodarsky Krai is divided into two districts: Novorossiysk subarea (NS) and Sochi subarea (SS). In accordance with the botanical-geographical zoning, NS is a part of the Crimean-Novorossiysk province of the Mediterranean region, SS is a part of the Euxine province of the Circumboreal region. On the basis of the botanical-geographical zoning of the Caucasus (Menitsky, 1991), NS corresponds to the North-Western Transcaucasia and includes the Anapa-Gelendzhik and Pshada-Dzhubga districts, and SS corresponds to the Western Transcaucasia, which we define to the Tuapse district and Sochi district (Fig.). The study area is bordered with the Taman district (Western Ciscaucasia) in the North-West, and the state border with the Republic of Abkhazia in the South-East. In the North and East, the border runs along the watersheds of ridges, covering the basins of rivers flowing into the Black Sea. The border between NS and SS is conditional, since the Tuapse vicinity has a smooth transition from submediterranean to Colchian landscapes. We draw the border between 
the two regions along the watershed that separates the basins of the River Shapsukho and River Nechepsukho (Dubovic, 2005; Zernov, 2006).

NS is represented by submediterranean and low-mountain forest landscapes (Guzhin et al., 1996; Belyuchenko, 2005). The submediterranean vegetation type is highly pronounced (Schiffers, 1953; Litvinskaya, 2004; Bohn et al., 2004; Demina et al., 2015a), forming a belt of hemixerophytic woodlands. Its diagnostic taxa are Juniperus excelsa M. Bieb., J. deltoides R.P. Adams, J. foetidissima Willd., Quercus pubescens Willd., Carpinus orientalis Mill., Pinus brutia var. pityusa (Steven) Silba, P. nigra subsp. pallasiana (Lamb.) Holmboe, and Pistacia atlantica subsp. mutica (Fisch. \& C.A. Mey.) Rech.f. The characteristic feature of NS, especially in the north-western part, is the wide distribution of upland-xerophytic vegetation, petrophytic and upland steppes.

The studied part of SS is represented by colchian forest and low-mountain-forest colchian landscapes (Ataev \& Bratkov, 2009). Its diagnostic taxa are Carpinus betulus L., Castanea sativa Mill., Fagus orientalis Lipsky, Quercus petraea (Matt.) Liebl., Q. robur subsp. imeretina (Steven ex Woronow) Menitsky, Alnus glutinosa subsp. barbata (C.A. Mey.) Yalt., and Taxus baccata L. A characteristic feature of SS vegetation is the polydominance of forest communities, which differs in the originality of the species composition, where mostly colchian features are expressed (Zernov, 2013). The presence of evergreen undergrowth forming by e.g. Prunus laurocerasus L., Rhododendron ponticum L., Buxus sempervirens L., Ilex colchica Pojark., Ruscus colchicus Yeo is also a characteristic feature of SS vegetation. In the North-West to the South-East, with an increase in precipitation, in the foothills and lowmountain parts of the Black Sea coast of Krasnodarsky Krai, the area, not occupied by forests, is significantly reduced. In SS, open habitats are mainly associated with anthropogenic influence on forests.

\section{Results and Discussion}

The research has resulted in a nomenclature list of Orchidaceae taxa of the Black Sea coast in Krasnodarsky Krai with clarification of their taxonomic status. In the study area, we have shown the presence of 52 taxa, including 41 species and eleven subspecies; besides there are ten hybrids.

\section{Nomenclature list of Orchidaceae taxa}

1. Anacamptis laxiflora subsp. dielsiana (Soó) H. Kretzschmar, Eccarius \& H. Dietr., 2007, The Orchid Genera: 98 (Kuropatkin \& Efimov, 2014; Litvinskaya, 2019).

EOrchis laxiflora subsp. dielsiana Soó, 1926, Notizbl. Bot. Gart. Berlin-Dahlem, 9: 910.

$=$ O. laxiflora auct. p.p. (Fomin \& Woronov, 1909). $=$ O. palustris auct. (Lipsky, 1899; Nevski, 1935; Grossheim, 1940; Dubovic, 2005; Averyanov, 2006; Zernov, 2006; Vakhrameeva et al., 2014; Litvinskaya, 2017; Ivanov, 2019).

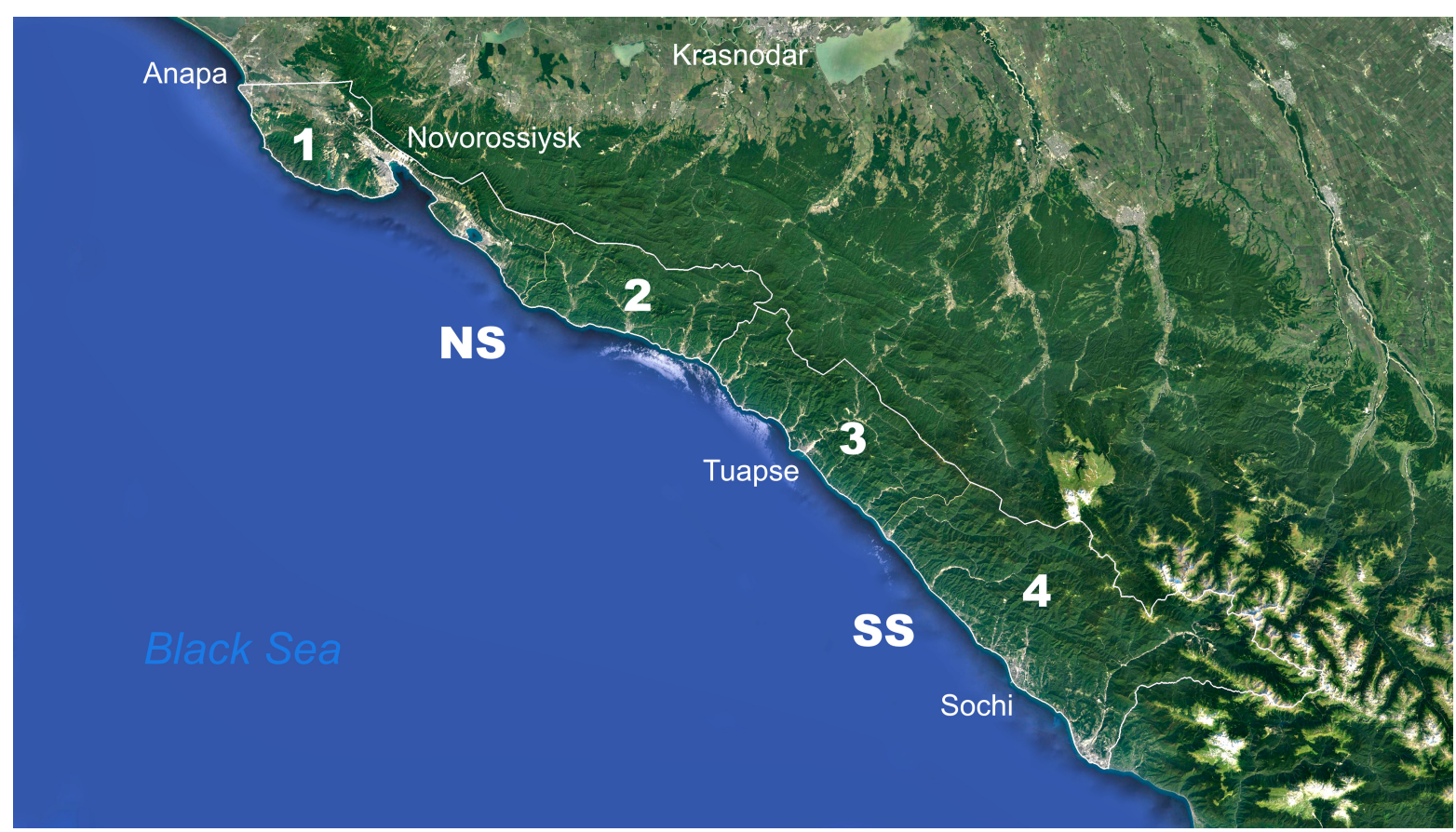

Fig. Borders of the study area of the Black Sea coast in Krasnodarsky Krai, Russia (Menitsky, 1991; Solodko, 1999; Dubovic, 2005; Zernov, 2006). Designation: NS - Novorossiysk subarea (1 - Anapa-Gelendzhik district, 2 - Pshada-Dzhubga district); SS - Sochi subarea (3 - Tuapse district, 4 - Sochi district). 
Distribution, occurrence and habitats in the study area. Anacamptis laxiflora subsp. dielsiana is a very rare taxon confined to swampy habitats, reliably known from three localities situated in NS (Popovich, 2013; Litvinskaya, 2017). Its local populations are numerous, but their sites are small (Popovich, 2013, 2019b). There is one old reference for SS, namely «in the Kuchuk-Dere forest» (Grinevetsky, 1916). There are no current data on the distribution of this taxon in SS. It is possible, that the location of the subspecies has been lost due to the expansion of human settlements and the destruction of floodplain wetlands.

Note. All reports of Orchis palustris Jacq. refer to Anacamptis laxiflora subsp. dielsiana. Anacamptis laxiflora is represented by several compact local populations on the Black Sea coast of Krasnodarsky Krai. In two of them (town Novorossiysk in the natural complex «Sudzhukskaya lagoon - Prilagunie» and in neighbourhoods of the reservoir near the village Sukko) plants have features, which clearly characterise them as the subsp. dielsiana. At the same time, in one population (Gelendzhik on the Tonkiy cape) and at the borders of the study area in the village Vityazevo, Anapa (Plantarium, 2020), plants have some characters of A. laxiflora subsp. elegans (Heuff.) Kuropatkin \& Efimov. Thus, the question of recognition of a particular subspecies on the Black Sea coast of Krasnodarsky Krai remains open.

2. Anacamptis morio subsp. caucasica (K. Koch) H. Kretzschmar, Eccarius \& H. Dietr., 2007, The Orchid Genera: 125 (Kuropatkin \& Efimov, 2014; Litvinskaya, 2019).

$\equiv$ Orchis morio var. caucasica K.Koch, 1849, Linnaea, 22: 280.

= Orchis morio auct. p.p. (Lipsky, 1899; Nevski, 1935; Flerov, 1938). = Orchis picta auct. (Nevski, 1935; Grossheim, 1940; Dubovic, 2005; Zernov, 2006; Vakhrameeva et al., 2014; Litvinskaya, 2017; Ivanov, 2019). EOrchis morio subsp. picta auct. (Averyanov, 2006; Zernov, 2013).

Distribution, occurrence and habitats in the study area. In NS, the taxon occurs sporadically. Large local populations are observed in meadowsteppe and steppe communities. For example, the largest local population of $A$. morio subsp. caucasica is located in the vicinity of the village Verkhnebakansky. In 2019, a total of 2809 generative plants were recorded in the area of $45000 \mathrm{~m}^{2}$. The taxon is found less frequently in shrub communities and juniper (Juniperus excelsa, J. foetidissima, J. deltoides) or hornbeam-oak (Carpinus orientalis, Quercus pubescens) woodlands. In SS, the taxon is rare, because open habitats are rare, represented mainly by secondary biotopes, namely forest edges, shrub thickets, roadsides, cuttings under high-voltage power lines, abandoned gardens (Averyanova, 2016).

Note. All reports of Orchis morio L. refer to Anacamptis morio subsp. caucasica (K.Koch) H. Kretzschmar, Eccarius \& H. Dietr. Orchis picta Loisel. ( $\equiv$ A. morio subsp. picta (Loisel.) Jacquet \& Scappat.) is a misidentification of $A$. morio subsp. caucasica (Kuropatkin \& Efimov, 2014).

3. Anacamptis pyramidalis (L.) Rich. 1817, De Orchid. Eur.: 33 (Lipsky, 1899; Nevski, 1935; Dubovic, 2005; Averyanov, 2006; Zernov, 2006; Vakhrameeva et al., 2014; Litvinskaya, 2017; Ivanov, 2019; Litvinskaya, 2019).

$\equiv$ Orchis pyramidalis L. 1753, Sp. Pl.: 940.

Distribution, occurrence and habitats in the study area. The species occurs sporadically along the entire Black Sea coast of Krasnodarsky Krai. The distribution of individuals within the populations is scattered. In NS, the species is confined to a strip of juniper (Juniperus excelsa, J. foetidissima, $J$. deltoides) woodlands, observed on coastal rocky slopes, less often in meadows and in the ecotone strip of hornbeam-oak (Carpinus orientalis, Quercus pubescens) woodlands and herb communities. In SS, it also grows mainly in ecotonic habitats, in meadows and in secondary woodlands in almost all river valleys (Averyanova, 2018a).

4. Cephalanthera damasonium (Mill.) Druce, 1906, Ann. Scott. Nat. Hist. 1906: 225 (Dubovic, 2005; Averyanov, 2006; Zernov, 2006; Vakhrameeva et al., 2014; Litvinskaya, 2017; Ivanov, 2019; Litvinskaya, 2019).

S Serapias damasonium Mill. 1768, Gard. Dict. ed. 8: 2.

$=$ Cephalanthera alba (Crantz) Simonk. (Fo$\min \&$ Woronov, 1909). = C. grandiflora (L.) Babing. (Nevski, 1935). = C. pallens (Sw.) S.B. Jundz. (Lipsky, 1899; Flerov, 1938).

Distribution, occurrence and habitats in the study area. The species occurs sporadically along the entire Black Sea coast of Krasnodarsky Krai, confined to forest communities, mainly oak (Quercus petraea, Q. pubescens), hornbeam (Carpinus betulus), beechhornbeam (Fagus orientalis, Carpinus betulus) and Colchic multi-dominant forests, rarely pine (Pinus brutia var. pityusa, $P$. nigra subsp. pallasiana) and juniper (Juniperus excelsa, J. foetidissima, J. deltoi$d e s$ ) forests. The distribution of individuals within the populations is scattered.

5. Cephalanthera epipactoides Fisch. \& C.A. Mey. 1854, Ann. Sci. Nat., Bot., IV, 1: 30 (Nevski, 
1935; Grossheim, 1940; Fateryga et al., 2020; Efimov, 2020). (Fig. 11S, Fig. 12S).

$=$ C. cucullata auct. (Lipsky, 1899; Fomin \& Woronov, 1909; Flerov, 1938; Zernov, 2006; Litvinskaya, 2017). = C. kurdica auct. (Averyanov, 2006; Ivanov, 2019). $=C$. floribunda auct. (Dubovic, 2005; Vakhrameeva et al., 2014; Litvinskaya, 2019).

Distribution, occurrence and habitats in the study area. Cephalanthera epipactoides is a very rare species, represented by a small number of specimens occurring singly or in small groups. In the study area, populations cover mainly the coastal strip NS from Anapa to Dzhubga (Litvinskaya, 2017; Fateryga et al., 2020). And we know several localities from SS, including the coastal slopes in the pine (Pinus brutia var. pityusa) forests near the village Soloniki (Personal communication: A. Solodko), the vicinity of the village Novomikhailovsky (Personal communication: A. Semenov and O. Semenova) and the vicinity of the village Gisel-Dere. The extremely northern location of $C$. epipactoides, noted by the authors of the study, is in a Protected Area, the coastal natural complex «Anapskoe vzmorye», located on the Abrau peninsula near the village Varvarovka. This record confirms the information of V.I. Lipsky, who found this taxon in the vicinity of Anapa in the late XIX century (LE). The largest population is located on the mountain Shkolnaya in the vicinity of Dzhubga. Its favourable conditions are primarily in light forest, shrubs, and edges of forests composed by Pinus brutia var. pityusa, Pinus nigra subsp. pallasiana, Juniperus deltoides, Quercus pubescens, and Carpinus orientalis. It occurs less commonly in herbal communities.

Note. All reports of Cephalanthera cucullata Boiss. \& Heldr., C. kurdica Bornm. ex Kraenzl. and C. floribunda Woronow refer to C. epipactoides. This species differs from $C$. cucullata by larger flowers with sepals longer than $20 \mathrm{~mm}$ (instead 14-20 mm), and a spur of 3-4 mm (instead 1-2 mm) long. The flower colour differs from $C$. kurdica, i.e. creamwhite or white with a yellowish tinge of the perianth, instead of bright pink, the epichile is narrower and pointed, narrow-hearted, but not wider and obtuse (Delforge, 2006; Fateryga et al., 2020).

6. Cephalanthera longifolia (L.) R.M. Fritsch, 1888, Oesterr. Bot. Z. 38: 81 (Fomin \& Woronov, 1909; Nevski, 1935; Grossheim, 1940; Dubovic, 2005; Averyanov, 2006; Zernov, 2006; Vakhrameeva et al., 2014; Litvinskaya, 2017; Ivanov, 2019; Litvinskaya, 2019).

$\equiv$ Serapias helleborine var. longifolia L. 1753, Sp. P1.: 950.
= Cephalanthera ensifolia Rich. (Lipsky, 1899).

Distribution, occurrence and habitats in the study area. The species is distributed all along the Black Sea coast of Krasnodarsky Krai. It is quite rare in NS, and rare in SS, where it occurs solitary or in small groups. The distribution of individuals within the populations is scattered. The species is confined to forest communities, mainly oak, oak-hornbeam and hornbeam (Quercus petraea, Q. pubescens, Carpinus betulus, C. orientalis), less often observed in beech (Fagus orientalis) and pine (Pinus brutia var. pityusa) forests and shrub communities.

7. Cephalanthera rubra (L.) Rich. 1817, De Orchid. Eur.: 38 (Lipsky, 1899; Nevski, 1935; Grossheim, 1940; Averyanov, 2006; Zernov, 2006; Vakhrameeva et al., 2014; Litvinskaya, 2017; Ivanov, 2019; Litvinskaya, 2019).

三Serapias rubra L. 1767, Syst. Nat. ed. 12, 2: 594.

Distribution, occurrence and habitats in the study area. The species occurs sporadically along the entire Black Sea coast of Krasnodarsky Krai, solitary or in small groups. It is confined to various forest communities. The distribution of individuals within the populations is scattered.

8. Dactylorhiza romana subsp. georgica (Klinge) Soó ex Renz \& Taubenheim, 1983, Notes Roy. Bot. Gard. Edinburgh 41: 271 (Efimov, 2020).

$\equiv$ Orchis mediterranea subsp. georgica Klinge, 1898, Trudy Imp. S.-Peterburgsk. Bot. Sada 17(1): 19. $\equiv$ O. georgica (Klinge) Medw. (Lipsky, 1899). $\equiv$ O. pseudosambucina subsp. georgica Klinge (Fomin \& Woronov, 1909; Flerov, 1938). = Orchis flavescens K. Koch (Grossheim, 1940; Zernov, 2006). = Dactylorhiza flavescens (K. Koch) Holub (Dubovic, 2005; Averyanov, 2006; Vakhrameeva et al., 2014; Litvinskaya, 2017; Ivanov, 2019; Litvinskaya, 2019).

Distribution, occurrence and habitats in the study area. Dactylorhiza romana subsp. georgica has a limited distribution on the Black Sea coast of Krasnodarsky Krai. In NS, this taxon is rare, recorded in the southeastern part, confined mainly to the dividing slopes of ridges (Kotsehur, Markotkh), at altitudes above $500 \mathrm{~m}$ a.s.1., in mountain meadows, less often in beech (Fagus orientalis) and hornbeam (Carpinus betulus) forests. For example, in 2019, a large population was discovered in a beech (Fagus orientalis) forest on the slope of the mountain «921» of the Kotsehur ridge, with several thousands of generative individuals (Fig. 15S). The distribution of individuals within the populations is compact-dispersed. To the south, it is noted on the Mikhailovsky pass and in the Tekos River basin, cape Kadosh near Tuapse (Litvinskaya, 2017). Below $500 \mathrm{~m}$ a.s.1., the taxon is confined to Quercus 
petraea forests. In the foothills and low-mountain parts of SS, the species is not recorded.

9. Dactylorhiza urvilleana (Steud.) H. Baumann \& Künkele, 1981, Mitt. Arbeitskreis Heimische Orchid. Baden-Württemberg 13: 240 (Averyanov, 2006; Vakhrameeva et al., 2014; Litvinskaya, 2017; Ivanov, 2019; Litvinskaya, 2019).

$\equiv$ Orchis urvilleana Steud. (Zernov, 2006).

$=O$. triphylla K. Koch $($ Grossheim, 1940).$=O$. cartaliniae (Klinge) Medw. (Lipsky, 1899). = Dactylorhiza amblyoloba (Nevski) Aver. (Dubovic, 2005).

Distribution, occurrence and habitats in the study area. The species is distributed all along the Black Sea coast of Krasnodarsky Krai. It is rare in NS and occurs sporadically in SS. It is found mainly in small groups, but in some local populations, forming clusters of 50-150 individuals (Popovich, 2013; Averyanova, 2019a). Dactylorhiza urvilleana prefers moist shady habitats: beech (Fagus orientalis) and hornbeam (Carpinus betulus), mixed colchian forests, floodplain seasonally waterlogged ash (Fraxinus excelsior) forests. The distribution of individuals within the populations is compact-dispersed.

10. Dactylorhiza viridis (L.) R.M. Bateman, Pridgeon \& M.W. Chase, 1997, Lindleyana 12: 129 (Litvinskaya, 2019; Efimov, 2020).

$\equiv$ Satyrium viride L. 1753, Sp. P1.: 944.

$\equiv$ Coeloglossum viride (L.) Hartm. (Nevski, 1935; Grossheim, 1940; Averyanov, 2006; Zernov, 2006; Vakhrameeva et al., 2014; Ivanov, 2019). Platanthera viridis (L.) Lindl. (Lipsky, 1899).

Distribution, occurrence and habitats in the study area. Dactylorhiza viridis is a very rare species, recorded on the border of NS and the Abinsky district (Zernov, 2000; Popovich, 2013). It is confined to meadows and ecotone belt and rarely occurs in oak-ash (Quercus petraea, Fraxinus excelsior) forests. In the foothills and low-mountain parts of SS, the species is not recorded.

11. Epipactis condensata Boiss. ex D.P. Young, 1970, Jahresber. Naturwiss. Vereins Wuppertal, 23: 106 (Efimov, 2008; Litvinskaya, 2017; Fateryga \& Fateryga, 2018; Ivanov, 2019; Litvinskaya, 2019; Efimov, 2020).

$\equiv$ E. helleborine subsp. condensata (Boiss. ex D.P. Young) H. Sund. 1980, Europ. Medit. Orchid., ed. 3: 41.

Distribution, occurrence and habitats in the study area. Epipactis condensata is a very rare species. Its current locations are known only in NS (Litvinskaya, 2017). An old sample (of 1914) is known from Khosta vicinity (SS), collected by Krasilnikov, stored in MW (MW0658771). The species is con- fined to pine (Pinus brutia var. pityusa), hornbeamoak (Carpinus orientalis, Quercus pubescens, $Q$. petraea) forests and shrub communities.

Note. Plants with purple-tinged leaves, previously accepted as Epipactis condensata subsp. kuenkeleana (Fateryga et al., 2014), were later put into synonymy to the nominative subspecies (Fateryga \& Fateryga, 2018). On the Black Sea coast of Krasnodarsky Krai, plants are common, both corresponding to the nominative subspecies and to the former subsp. kuenkeleana. They are not separated geographically. Therefore, we accept the position of Fateryga \& Fateryga (2018), and consider the latter taxon as a phenotypic form, confined to shady forest communities:

Epipactis condensata var. kuenkeleana (Akhalk., H. Baumann, R. Lorenz \& Mosul.) Popovich, comb. nov. Basionym: Epipactis viridiflora subsp. kuenkeleana Akhalk., H. Baumann, R. Lorenz \& Mosul. in H. Baumann \& R. Lorenz, 2005, J. Eur. Orch. 37(3): 711.

12. Epipactis euxina Fateryga, Popovich \& Kreutz, 2018, Phytotaxa, 358(3): 279 (Fateryga \& Fateryga, 2018; Litvinskaya, 2019; Efimov, 2020) (Fig. 1S, Fig. 2S).

Distribution, occurrence and habitats in the study area. This species is known only from the type locality (NS) in the nature monument «Roshcha sosny pitsundskoy "Dzhankhotskaya"»: «Gelendzhik District, vicinity of khutor Dhzankhot, Mt Svyataya Nina» (Fateryga et al., 2018b).

Note. In contrast to the closely related species Epipactis persica, this newly described endemic has the longest pedicels, about equal to the length of the ovary, but not shorter; the epichile's length appreciably exceeds the width, but not approximately equal to the width; the viscidium is underdeveloped or absent (viscidium is well defined in E. persica) (Fateryga et al., 2018b). Flowering occurs in the first half of June, rather than in July. Epipactis euxina is confined to more xerophilic conditions.

13. Epipactis helleborine subsp. tremolsii (Pau) E. Klein, 1979, Orchidee (Hamburg), 30(2): 49 (Fateryga \& Fateryga, 2018).

$\equiv$ E. tremolsii Pau, 1914, Bol. Soc. Aragonesa Ci. Nat. 13: 43.

$=$ E. helleborine auct. p.p. (Dubovic, 2005; Averyanov, 2006; Zernov, 2006; Vakhrameeva et al., 2014; Ivanov, 2019; Litvinskaya, 2019). = E. latifolia auct. (Lipsky, 1899; Nevski, 1935; Grossheim, 1940).

Distribution, occurrence and habitats in the study area. This taxon occurs sporadically along the entire Black Sea coast of Krasnodarsky Krai. It is 
quite common in NS, and rarer in SS, except for two large, isolated populations in Sochi: in the sanatorium «Metallurg» and on the terrencure «Path of health». The taxon is confined to various forest communities, shrubby thickets. And it is less frequently observed in the ecotone belt and disturbed habitats. The distribution of individuals within the populations is scattered.

Note. We accept the view of Fateryga \& Fateryga (2018), that subsp. tremolsii is widespread in the Crimea and the North Caucasus, including E. helleborine subsp. levantina Kreutz, Óvári \& Shifman and E. turcica Kreutz.

14. Epipactis krymmontana Kreutz, Fateryga \& Efimov, 2014, Phytotaxa, 172(1): 24 (Fateryga \& Fateryga, 2018; Fateryga et al., 2018b; Litvinskaya, 2019; Efimov, 2020).

Distribution, occurrence and habitats in the study area. In NS, one location of this species is known in the nature monument «Roshcha sosny pitsundskoy "Dzhankhotskaya"»: «Gelendzhik District, vicinity of khutor Dhzankhot, Mt. Svyataya Nina» (Fateryga et al., 2018b). Plants are recorded in a pine (Pinus brutia var. pityusa) forest damaged by wildfire.

Note. The main diagnostic character of this Crimean-Novorossiysk endemic, which distinguishes it from the closely related species $E$. condensata, is the absence of a viscidium, and the associated obligate self-pollinating (Fateryga et al., 2014).

15a. Epipactis leptochila (Godfery) Godfery subsp. leptochila (Fateryga \& Fateryga, 2018; Fateryga et al., 2018b; Litvinskaya, 2019). (Fig. 3S:A,B).

$\equiv$ E. viridiflora var. leptochila Godfery, 1919, J. Bot. 57: 38 .

Distribution, occurrence and habitats in the study area. We know several locations of this taxon on the border of NS and in the Abinsky district, on the ridges of the Markotkh and Kotsehur (Fateryga et al., 2018b; Popovich, 2019a; Plantarium, 2020). A new location of Epipactis leptochila subsp. leptochila was found in the vicinity of the village Verkhnebakansky in the Plisova gorge (Fig. 5S, Fig. 6S). The taxon is confined to shady broad-leaved forests.

15b. Epipactis leptochila subsp. neglecta Kümpel, 1982, Mitt. Arbeitskreises Heimische Orchideen, 11: 29 (Fateryga \& Fateryga, 2018; Fateryga et al., 2018b; Litvinskaya, 2019; Efimov, 2020). (Fig. 7S, Fig. 8S).

$\equiv$ E. neglecta (Kümpel) Kümpel, 1996, Die wildwachsenden Orchideen der Rhön: 67.

Distribution, occurrence and habitats in the study area. We know one population of Epipactis leptochila subsp. neglecta in SS, in the Khosta river basin on the border of the Khosta department of the Caucasian State Nature Biosphere Reserve. The habitat is a mixed dead-blooded beech-yew (Fagus orientalis, Taxus baccata) forest with linden (Tilia begoniifolia) and maples (Acer campestre, A. cappadocicum) on the western slope of the gorge (Fateryga et al., 2018b).

Note. Unlike the typical subspecies, subsp. neglecta has its lateral margins of the epichile not rolled up and the viscidium is usually absent.

16. Epipactis microphylla (Ehrh.) Sw. 1800, Kongl. Vetensk. Acad. Nya Handl. 21: 232 (Nevski, 1935; Grossheim, 1940; Dubovic, 2005; Averyanov, 2006; Zernov, 2006; Vakhrameeva et al., 2014; Litvinskaya, 2017; Fateryga \& Fateryga, 2018; Ivanov, 2019; Litvinskaya, 2019).

三 Serapias microphylla Ehrh. 1789, Beitr. Naturk. [Ehrhart], 4: 42.

Distribution, occurrence and habitats in the study area. Epipactis microphylla is reliably known in NS of the Black Sea coast of Krasnodarsky Krai. It is a rare species, mainly presented by solitary plants or small groups. The species is confined to diverse forest communities: beech (Fagus orientalis) and hornbeam (Carpinus betulus), oak (Quercus petraea), hornbeam-oak (Carpinus orientalis, Quercus pubescens) and pine (Pinus brutia var. pityusa) forests.

17. Epipactis muelleri Godfery, 1921, J. Bot. 59: 106 (Fateryga \& Fateryga, 2018; Fateryga et al., 2018b; Litvinskaya, 2019). (Fig. 3S, Fig. 4S).

Distribution, occurrence and habitats in the study area. Epipactis muelleri is a very rare species, known from several locations in NS (Fateryga et al., 2018b; Popovich, 2019a). A new location of E. muelleri was found in the vicinity of the village Verkhnebakansky in the Plisova gorge (Fig. 2S:C,D). The species is confined to shady beech (Fagus orientalis), hornbeam (Carpinus betulus), and rarely oak (Quercus petraea) forests.

Note. The Black Sea coast of Krasnodarsky Krai is home to plants of E. muelleri var. saltuaria Kreutz, which lack a viscidium and have small flowers with a small heart-shaped epichile without or with indistinct tubercles at its base (Kreutz et al., 2018).

18. Epipactis persica (Soó) Hausskn. ex Nannf. 1946, Bot. Not. 1946(1): 21 (Fateryga \& Fateryga, 2018; Fateryga et al., 2018b; Litvinskaya, 2019).

三 Helleborine persica Soó, 1927, Repert. Spec. Nov. Regni Veg. 24: 36.

Distribution, occurrence and habitats in the study area. This species has been recorded in NS, on the Markotkh and Kotsehur ridges, and on mount Mikhailovka. It is confined to shady beech (Fagus orientalis) and hornbeam (Carpinus betulus) forests (Popovich, 2019a). This species is found mainly as single individuals. We assume that further targeted research will result in finding Epipactis persica in SS, too. 
19. Epipactis pontica Taubenheim, 1975, Orchidee (Hamburg), 26(2): 68 (Averyanova, 2013; Litvinskaya, 2017; Fateryga \& Fateryga, 2018; Ivanov, 2019; Litvinskaya, 2019; Efimov, 2020) (Fig. 9S, Fig. 10S).

Distribution, occurrence and habitats in the study area. In SS, there are several, often large, populations. There is, in the interfluve of Eastern and Western Khosta, one small population in the Kudepsta River basin (Averyanova, 2013; Litvinskaya, 2017) new locations of Epipactis pontica are found on mount Ovsyannikova and in the vicinity of the village Thagapsh.

20. Gymnadenia conopsea (L.) R. Br. 1813, in Aiton, Hortus Kew. 5: 191 (Lipsky, 1899; Nevski, 1935; Grossheim, 1940; Dubovic, 2005; Averyanov, 2006; Zernov, 2006; Vakhrameeva et al., 2014; Ivanov, 2019; Litvinskaya, 2019).

EOrchis conopsea L. 1753, Sp. P1.: 942.

Distribution, occurrence and habitats in the study area. Gymnadenia conopsea is a rare species on the Black Sea coast of Krasnodarsky Krai. In NS, it is known mainly on the Markotkh ridge and the Kotsehur ridge, in the vicinity of the khutors Dzhankhot and Dzhubga (MW0637947; Popovich, 2019a). Gymnadenia conopsea is indicated in the Utrish State Nature Reserve (Timukhin, 2017). In SS, in the lowmountain part, herbarium specimens are known from the vicinity of Tuapse (MW0658489, MW0658490). Other locations are noted in the middle and high mountain zones. The species is confined to mountain meadows, and it is observed in clearings along power lines and in thickets of shrubs. The distribution of individuals within the populations is scattered.

21. Himantoglossum caprinum (M. Bieb.) Spreng. 1826. Syst. Veg. ed. 16 [Sprengel] 3: 694 (Dubovic, 2005; Averyanov, 2006; Zernov, 2006; Vakhrameeva et al., 2014; Litvinskaya, 2017; Ivanov, 2019; Litvinskaya, 2019).

$\equiv$ Orchis caprina M. Bieb. 1819, Fl. Taur. Cauc. 3: 602 .

= Himantoglossum affine (Boiss.) Schltr. 1918, Repert. Spec. Nov. Regni Veg. 15: 287.

Distribution, occurrence and habitats in the study area. The main part of the population in the North-Western Caucasus is located in NS. The largest population is located in the vicinity of the village Verkhnebakansky (Fig. 16S). In 2019, a total of 8480 individuals of different age classes were recorded in an area of $45000 \mathrm{~m}^{2}$ (Popovich, 2019a). Quite large populations are located on the Markotkh ridge. Also, the species is noted on the Tuaphat ridge and the Abrau peninsula (Demina et al., 2015b; Litvinskaya, 2017). The distribution of individuals within the populations is compact-dispersed.
Note. The plants located on the Black Sea coast of Krasnodarsky Krai, as well as in the whole area of the North-Western Caucasus and in Crimea (Yena, 2012; Popovich, 2019a), have no speckling and are not long villose at the base of the lip (the surface is almost smooth). These characters correspond to Himantoglossum affine (Boiss.) Schltr. On the basis of an in-depth analysis, it is proved that $H$. caprinum and $H$. affine are the same species (Sramkó et al., 2012).

22. Himantoglossum comperianum (Steven) P. Delforge, 1999. Naturalistes Belges 80(3): 401 (Efimov, 2020).

E Orchis comperiana Steven, 1829, Nouv. Mém. Soc. Imp. Natural. Moscou 1, 8: 259.

$\equiv$ Comperia comperiana (Steven) Asch. \& Graebn. (Makarova \& Shulakov, 2011, Vakhrameeva et al., 2014, Litvinskaya, 2017; Ivanov, 2019; Litvinskaya, 2019).

Distribution, occurrence and habitats in the study area. Himantoglossum comperianum was found in 2009 (Makarova \& Shulakov, 2011). It is known on the basis of two specimens collected in the vicinity of the village Khleborob in SS (MHA).

Note. We accept the position of Delforge (1999) and Bateman et al. (2017), who included the genus Comperia K. Koch in Himantoglossum Spreng. on the basis of morphological and molecular studies.

23. Limodorum abortivum (L.) Sw. 1799, Nova Acta Regiae Soc. Sci. Upsal. 6: 80 (Lipsky, 1899; Fomin \& Woronov, 1909; Nevski, 1935; Grossheim, 1940; Averyanov, 2006; Zernov, 2006; Vakhrameeva et al., 2014; Litvinskaya, 2017; Ivanov, 2019; Litvinskaya, 2019).

三Orchis abortiva L. 1753, Sp. Pl.: 943.

Distribution, occurrence and habitats in the study area. Limodorum abortivum is distributed all along the Black Sea coast of Krasnodarsky Krai: NS (quite rare), SS (sporadically). It is confined to various forest communities, mainly to oak (Quercus petraea, Q. pubescens), hornbeam (Carpinus betulus), beechhornbeam (Fagus orientalis, Carpinus betulus) and mixed colchian forests, rarely pine (Pinus brutia var. pityusa) forests and shrubs. The distribution of individuals within the populations is scattered.

24. Neotinea tridentata (Scop.) R.M. Bateman, Pridgeon \& M.W. Chase, 1997, Lindleyana 12(3): 122 (Kuropatkin \& Efimov, 2014; Litvinskaya, 2019). $\equiv$ Orchis tridentata Scop. (Lipsky, 1899; Fomin \& Woronov, 1909; Nevski, 1935; Flerov, 1938; Grossheim, 1940; Dubovic, 2005; Averyanov, 2006; Zernov, 2006; Vakhrameeva et al., 2014; Litvinskaya, 2017; Ivanov, 2019). 
Distribution, occurrence and habitats in the study area. Neotinea tridentata is a fairly common species in NS, but to the south-east, the number of localities and population size decreases considerably due to a reduction of open habitats. Numerous local populations are noted on the Markotkh ridge, in the vicinity of the village Verkhnebakansky, on Shkolnaya mount in the vicinity of the village Dzhubga, on mount «Three Brothers» in the vicinity of Tuapse. Some populations are found on the Abrau peninsula. In SS, in the Dederkoi gorge, in the Svirsky gorge, in the interfluves of the Western Khosta River, Eastern Khosta River and River Kudepsta, as well as in the middle reaches of River Mzymta. The taxon is confined to herbaceous plant communities. It is observed in meadows and meadow-steppe communities, in juniper (Juniperus excelsa, J. foetidissima, J. deltoides) woodlands and clearings in hornbeam-oak (Carpinus orientalis, Quercus pubescens) forests, in the ecotone represented by shrub communities, anthropogenically disturbed habitats.

25. Neotinea ustulata (L.) R.M. Bateman, Pridegon \& M.W. Chase, 1997, Lindleyana 12: $122(\mathrm{Ku}-$ ropatkin \& Efimov, 2014; Litvinskaya, 2019).

$\equiv$ Orchis ustulata L. (Lipsky, 1899; Nevski, 1935; Flerov, 1938; Grossheim, 1940; Dubovic, 2005; Averyanov, 2006; Zernov, 2006; Vakhrameeva et al., 2014; Litvinskaya, 2017; Ivanov, 2019).

Distribution, occurrence and habitats in the study area. Neotinea ustulata is a very rare species. There are data of this species in NS (Flerov \& Flerov, 1926; Zernov, 2000; Dubovic, 2005; Lipka, 2009). We know two closely located sites on the Markotkh ridge above the village Hajduk (Popovich, 2013; Plantarium, 2020). In SS, N. ustulata is specified from the vicinity of the village Novomikhailovsky (Personal communication: A. Semenov and O. Semenova). The species is confined to herbaceous plant communities: meadows and meadow-steppe communities.

26. Neottia nidus-avis (L.) Rich. 1817, De Orchid. Eur.: 37 (Lipsky, 1899; Nevski, 1935; Grossheim, 1940; Averyanov, 2006; Zernov, 2006; Vakhrameeva et al., 2014; Ivanov, 2019; Litvinskaya, 2019).

三Ophrys nidus-avis L. 1753, Sp. P1.: 945.

Distribution, occurrence and habitats in the study area. This species is found sporadically along the entire Black Sea coast of Krasnodarsky Krai, in forest, mainly mesophytic, plant communities. Neottia nidus-avis often forms clusters of 100-300 individuals.

27. Neottia ovata (L.) Bluff \& Fingerh. 1838, Comp. Fl. German., ed. 2, 2: 435. $\equiv$ Ophrys ovata L. 1753, Sp. Pl.: 946.

$\equiv$ Listera ovata (L.) R. Br. (Lipsky, 1899; Nevski, 1935; Grossheim, 1940; Averyanov, 2006; Zernov, 2006; Vakhrameeva et al., 2014; Litvinskaya, 2017; Ivanov, 2019; Litvinskaya, 2019).

Distribution, occurrence and habitats in the study area. This mesophytic species is confined to shady wet forest communities. In NS, Neottia ovata is rare due to smaller areas with suitable illumination and humidity conditions, i.e. floodplain ash (Fraxinus excelsior) forests («Tsemesskaya grove» and forest area «Bolshye Yasynki»), in places where ground water reaches the surface. It is known from the watershed slopes of the Markotkh ridge (mainly northern exposure), Kotsekhur ridge and Mikhailovka mountain, in beech (Fagus orientalis) and hornbeam (Carpinus betulus) forests. The species is more common closer to Tuapse. It is found sporadically in almost all gorges in SS. Separate populations are numerous on Bytkha and Ovsyannikov mounts, between the River Zapadnaya Khosta and the River Vostochnaya Khosta.

28. Ophrys apifera Huds. 1762, Fl. Angl. (Huds.): 340 (Nevski, 1935; Grossheim, 1940; Averyanov, 2006; Zernov, 2006; Vakhrameeva et al., 2014; Litvinskaya, 2017; Ivanov, 2019; Litvinskaya, 2019).

Distribution, occurrence and habitats in the study area. Ophrys apifera is a very rare species. In NS, it is mostly confined to herbaceous plant communities. Currently, the largest $O$. apifera population (250 plants) is found in thermophilic meadows, where the dominant mediterranean species is Deschampsia media (Gouan) Roem. \& Schult., located in the Protected Area «Prilagunie» and in adjacent areas. It is rarely seen in swampy meadows and ash (Fraxinus excelsior) floodplain forests (in Gelendzhik on the Thin Cape and in Novorossiysk in the «Pioneer grove»), in petrophytic-steppe communities, in clearings of sparse oak-hornbeam (Quercus pubescens, Carpinus orientalis) and juniper (Juniperus deltoides) communities (Abrau peninsula and Shkolnaya mount). We found a new location of $O$. apifera in Gelendzhik on cape Tonkiy in 2019. The species is rare in SS, where it is usually confined to the ecotones: forest edges, verges of forest roads, and secondary small woodland. In addition to previously known localities (Litvinskaya, 2017), eight localities were noted here. In one of them (interfluve of the River Zapadnaya Khosta and River Vostochnaya Khosta), we found six subpopulations, in which the number of individuals varied from 2-3 individuals to 50 individuals (Averyanova, 2017a). In the cluster of the Sochi Arboretum in Sochi city, there were up to 250 individuals in artificial forest plantings (Soltani, 2015). 
29. Ophrys mammosa subsp. caucasica (Woronow ex Grossh.) Soó, 1973, Acta Bot. Acad. Sci. Hung. 18(3/4): 383 (Fateryga et al., 2018a).

$\equiv$ O. caucasica Woronow ex Grossh., 1928, Fl. Kavk. [Grossh.], 1: 261 (Grossheim, 1940; Averyanov, 2006; Vakhrameeva et al., 2014; Litvinskaya, 2017; Ivanov, 2019; Litvinskaya, 2019).

= O. mammosa auct. p.p. (Averyanov, 2006; Zernov, 2006). = O. taurica auct. (Grossheim, 1940; Litvinskaya, 2017).

Distribution, occurrence and habitats in the study area. Ophrys mammosa subsp. caucasica is rarely found in NS. It prefers the coastal slopes of ridges, confined to open habitats. This taxon is noted in petrophyte communities and petrophytic steppe, in juniper (Juniperus excelsa, J. foetidissima, J. deltoides) woodlands, in clearings and in ecotones of hornbeam-oak (Carpinus orientalis, Quercus pubescens) forests. The taxon is even rarer in SS. It is noted in the vicinity of the village Detlyazhka (Timukhin \& Tuniyev, 2018), as well as on «Three Brothers» mount, on the seaside slope near the railway station in Gizel-Dere, in the Svirskoe gorge and in the vicinity of Soloniki. Ophrys mammosa subsp. caucasica is confined to sparse shrub communities and oak-hornbeam (Quercus pubescens, $Q$. petraea, Carpinus orientalis) forests in SS. Plants are recorded solitary or in small groups.

Note. On the Black Sea coast of Krasnodarsky Krai, as well as in the whole of the North-Western Caucasus, only subsp. caucasica is known (Fateryga et al., 2018a). All reports of Ophrys taurica (Agg.) Nevski refer to O. mammosa subsp. caucasica.

30. Ophrys oestrifera M. Bieb. 1808, Fl. Taur.-Caucas. 2: 369 (Lipsky, 1899; Nevski, 1935; Grossheim, 1940; Averyanov, 2006; Vakhrameeva et al., 2014; Litvinskaya, 2017; Fateryga et al., 2018a; Ivanov, 2019; Litvinskaya, 2019).

$=O$. cornuta Steven ex M. Bieb. (Fomin \& Woronov, 1909; Flerov, 1938). = O. bremifera Steven ex M. Bieb. $=O$. oestrifera subsp. bremifera (Steven ex M. Bieb.) K. Richt. (Averyanov, 2006). $=O$. abchasica (Kümpel) P. Delforge.

Distribution, occurrence and habitats in the study area. This species is distributed along the Black Sea coast of Krasnodarsky Krai, It is quite rare in NS and occurs sporadically in SS. Ophrys oestrifera is more common in the south-east of the study area (Averyanova, 2015). Ophrys oestrifera has a higher ecological amplitude than the previous taxon. Some populations are confined to petrophytic steppe, rocky clearings in juniper (Juniperus excelsa, J. foetidissima, J. deltoides) and hornbeam-oak (Carpinus orien- talis, Quercus pubescens) forests, shrub communities, and less frequently to seasonally waterlogged meadows. Others occur in shady beech (Fagus orientalis) and hornbeam (Carpinus betulus) forests, as well as anthropogenic disturbed habitats. Some populations are characterised by a high number of individuals and divided into small subpopulations.

31. Orchis mascula (L.) L. 1755, Fl. Suec., ed. 2: 310 (Lipsky, 1899; Fomin \& Woronov, 1909; Nevski, 1935; Grossheim, 1940; Dubovic, 2005; Averyanov, 2006; Zernov, 2006; Vakhrameeva et al., 2014; Litvinskaya, 2017; Ivanov, 2019; Litvinskaya, 2019).

$\equiv$ O. morio var. mascula L. 1753, Sp. P1.: 224.

Distribution, occurrence and habitats in the study area. This species is distributed mostly sporadically along the Black Sea coast of Krasnodarsky Krai. In $\mathrm{SS}$, the species is quite common. The distribution of individuals within its extended populations is scattered. Some of them harbour numerous individuals. Orchis mascula is confined to various plant communities. It is relatively rare in beech (Fagus orientalis) forests, but not noted in swampy floodplain forests and swampy meadows.

32. Orchis militaris subsp. stevenii (Rchb. f.) B. Baumann, H. Baumann, R. Lorenz \& Ruedi Peter, 2003, J. Eur. Orchideen 35: 179 (Kuropatkin \& Efimov, 2014).

$\equiv$ O. stevenii Rchb. (Litvinskaya, 2019).

$=$ O. militaris auct. p.p. (Lipsky, 1899; Nevski, 1935; Grossheim, 1940; Dubovic, 2005; Averyanov, 2006; Zernov, 2006; Vakhrameeva et al., 2014; Litvinskaya, 2017; Ivanov, 2019; Litvinskaya, 2019).

Distribution, occurrence and habitats in the study area. This taxon is very rare in NS. We know locations in the ecotones, in meadows and ash-oak (Fraxinus excelsior, Quercus robur subsp. pedunculiflora) forests in the vicinity of the village Raevskaya; in Dzhubga on Shkolnaya mount, in meadow communities on the edge with juniperoak (Juniperus deltoides, Quercus pubescens) low-growth forests. In SS, it is recorded from the vicinity of Tuapse and in the settlement Lazarevskoe and the villages Soloniki, Vishnevka, Matrosskaya Schel, from Magri to Chemitokvadzhe (MW; Litvinskaya, 2017), Novomikhailovskiy (Personal communication: A. Semenov and O. Semenova). We personally confirmed one new location, located on the right slope of the Svirsky gorge.

Note. We support the view of Averyanov (2006) that Orchis militaris subsp. stevenii is a stabilised hybrid (O. militaris L. $\times O$. simia Lam.). It replaces the type subspecies on the Black Sea coast of Krasnodarsky Krai. 
33. Orchis provincialis Balb. ex Lam. \& DC. 1806, Syn. Pl. Fl. Gal.: 169 (Nevski, 1935; Flerov, 1938; Grossheim, 1940; Dubovic, 2005; Averyanov, 2006; Zernov, 2006; Vakhrameeva et al., 2014; Litvinskaya, 2017; Ivanov, 2019; Litvinskaya, 2019).

Distribution, occurrence and habitats in the study area. This species is distributed only in SS, forming extended populations in Colchic multidominant forests and in beech-hornbeam (Fagus orientalis, Carpinus betulus) forests. The population can reach a high number of individuals, especially in the south-eastern part of SS.

34. Orchis punctulata Steven ex Lindl. 1835, Gen. Sp. Orchid. Pl.: 273 (Nevski, 1935; Grossheim, 1940; Dubovic, 2005; Averyanov, 2006; Zernov, 2006; Vakhrameeva et al., 2014; Litvinskaya, 2017; Ivanov, 2019; Litvinskaya, 2019).

$=$ O. sepulchralis (Rchb. f.) Boiss. \& Heldr. var. viridiflora Klinge (Fomin \& Woronov, 1909; Flerov, 1938). = O. schelkownikowii Woronow (Nevski, 1935; Flerov, 1938).

Distribution, occurrence and habitats in the study area. This species is quite common in NS, confined to the ecotone belt, shrub thickets, juniper (Juniperus excelsa, $J$. foetidissima, $J$. deltoides) woodlands, hornbeamoak (Carpinus orientalis, Quercus pubescens) forests, meadow and meadow-steppe. Large populations are observed on abandoned agricultural lands (Fig. 17S). Several Orchis punctulata populations are noted in SS from Magri to Lazarevskaya, where the number of individuals decreases to the south-east part. In the south-east of Volkonka there are only a few locations. Between the River Sochi and the River Psou, there were twice found only some solitary plants, which were extinct 5-7 years ago.

35. Orchis purpurea subsp. caucasica (Regel) B. Baumann, H. Baumann, Lorenz \& Peter, 2003, J. Eur. Orchideen 35: 182 (Kuropatkin \& Efimov, 2014; Litvinskaya, 2019).

$\equiv$ O. caucasica Regel, 1869, Index Seminum (LE) 1868 (Suppl.): 22.

$=O$. purpurea auct. p.p. (Fomin \& Woronov, 1909; Grossheim, 1940; Dubovic, 2005; Averyanov, 2006; Zernov, 2006; Vakhrameeva et al., 2014; Litvinskaya, 2017; Ivanov, 2019). = O. fusca auct. (Lipsky, 1899; Flerov, 1938). = O. maxima auct. (Nevski, 1935).

Distribution, occurrence and habitats in the study area. This taxon is distributed all along the Black Sea coast of Krasnodarsky Krai, occurs as solitary plants or in small groups. It is quite rare in NS, but occurs sporadically in SS. It occurs sporadically in SS, forming extended populations. The distribution of indi- viduals within the populations is scattered. Some of them are numerous. It is associated with forest communities, including oak (Quercus petraea, Q. robur), oak-hornbeam (Q. petraea, Carpinus betulus), beechhornbeam (Fagus orientalis, C. betulus) and polydominant forests of the colchian type. It is often found along roadsides and in ecotone plant communities.

36. Orchis simia Lam. 1779, Fl. Franç. 3: 507 (Lipsky, 1899; Nevski, 1935; Flerov, 1938; Grossheim, 1940; Dubovic, 2005; Averyanov, 2006; Zernov, 2006; Vakhrameeva et al., 2014; Litvinskaya, 2017; Ivanov, 2019; Litvinskaya, 2019).

Distribution, occurrence and habitats in the study area. Orchis simia is one of the most common Orchidaceae species in NS, confined to juniper (Juniperus excelsa, J. foetidissima, J. deltoides), pine (Pinus brutia var. pityusa) and hornbeam-oak (Carpinus orientalis, Quercus pubescens) forests and woodlands, noted in steppe, meadow-steppe and petrophytic plant communities, in shrub thickets and anthropogenically disturbed habitats (abandoned agricultural land). On the contrary, in SS, O. simia is a very rare species with isolated individuals in the vicinity of the village Vishnevka (Timukhin \& Tuniyev, 2018). The locations in the vicinities of Tuapse, Magri and Khosta (Litvinskaya, 2017) require confirmation. We could not find them.

37. Platanthera bifolia (L.) Rich. 1817, De Orchid. Eur.: 35 (Lipsky, 1899; Fomin \& Woronov, 1909; Nevski, 1935; Flerov, 1938; Grossheim, 1940; Dubovic, 2005; Averyanov, 2006; Zernov, 2006; Vakhrameeva et al., 2014; Litvinskaya, 2017; Ivanov, 2019; Litvinskaya, 2019).

三Orchis bifolia L. 1753, Sp. P1.: 939.

Distribution, occurrence and habitats in the study area. Platanthera bifolia is a rare species in NS, mostly confined to mesophytic broad-leaved forests. In SS, the species is common, found in various forest plant communities. The distribution of individuals within the populations is scattered.

38. Platanthera chlorantha (Custer) Rchb. 1829, in Mössler \& Rchb., Handb. Gewächsk. ed. 2, 2: 1565 (Nevski, 1935; Flerov, 1938; Grossheim, 1940; Dubovic, 2005; Averyanov, 2006; Zernov, 2006; Vakhrameeva et al., 2014; Litvinskaya, 2017; Ivanov, 2019; Litvinskaya, 2019).

$\equiv$ Orchis chlorantha Custer, 1827, Neue Alp. 2: 400.

$=$ Platanthera montana (F.W. Schmidt) Rchb. f. (Lipsky, 1899).

Distribution, occurrence and habitats in the study area. Platanthera chlorantha is a quite rare species in NS, confined to more xerophytic conditions than $P$. 
bifolia, such as oak-hornbeam (Carpinus orientalis, Quercus petraea, $Q$. pubescens) forests, glades in pine (Pinus brutia var. pityusa, P. nigra subsp. pallasiana) and juniper(Juniperus deltoides) forests, in the ecotone belt, less often in hornbeam and hornbeam-beech (Carpinus betulus, Fagus orientalis) forests, meadow and meadow-steppe. Most of the locations known in SS (Litvinskaya, 2017; Timukhin \& Tuniyev, 2018) are apparently incorrect. Plants with morphological characteristics typical for $P$. chlorantha were found only at one place: in the River Kuapse valley. All other numerous records were related to $P$. bifolia individuals. There are old collected specimens of this species from the vicinity of the village Ashe and the settlement Khosta (MW0658579; MW0658581), and more recent collections from the village Agoy and between the railway stations of Volkonka and Soloniki (MW1004321, MW1004322).

39. Serapias orientalis subsp. feldwegiana $(\mathrm{H}$. Baumann \& Künkele) Kreutz, 2004, Kompend. Eur. Orchid.: 138 (Efimov, 2020) (Fig. 13S, Fig. 14S).

$\equiv S$. feldwegiana H. Baumann \& Künkele, 1989, Mitt. Arbeitskreis Heimische Orchid. Baden-Württemberg 21: 763 (Averyanova, 2019b; Litvinskaya, 2019).

$=S$. vomeracea auct. (Nevski, 1935; Grossheim, 1940; Averyanov, 2006; Zernov, 2006; Vakhrameeva et al., 2014; Litvinskaya, 2017; Ivanov, 2019). $=S$. pseudocordigera auct. (Lipsky, 1899). $=$ S. longipetala auct. (Fomin \& Woronov, 1909).

Distribution, occurrence and habitats in the study area. This taxon is absent in NS. Obviously, the northeastern border of the global range of this taxon runs along the border of NS and SS, covering the foothills and low mountains from Agui-Shapsug in the vicinity of Tuapse to the state border with Abkhazia. This orchid prefers open or ecotone habitats. Usually, populations are characterised by non-numerous individuals. But in the Zapadnaya Khosta River basin and Matsesta River basin, we found clusters of $300-500$ individuals (Averyanova, 2018b).

Note. This taxon is misidentified as Serapias vomeracea (Burm. f.) Briq. in Russian literature. However, S. orientalis subsp. feldwegiana plants from SS have clear characters that distinguish it from $S$. vomeracea (Burm. f.) Briq., as follows: stem leaves do not reach the inflorescence; bracts distinctly longer than the flower; the epichile two or more times exceeds the hypochile in length; a broad, almost triangular hypochile, the length of which exceeds its width; high basal bosses at the base of the hypochile; pollinia are dark purple. On this basis, we believe, that the plants, presented in SS, belong to $S$. orientalis subsp. feldwegiana (Averyanova, 2019b).
40. Spiranthes spiralis (L.) Chevall. 1827, Fl. Gén. Env. Paris 2: 330 (Nevski, 1935; Flerov, 1938; Grossheim, 1940; Averyanov, 2006; Zernov, 2006; Vakhrameeva et al., 2014; Litvinskaya, 2017; Ivanov, 2019; Litvinskaya, 2019).

$\equiv$ Ophrys spiralis L. 1753, Sp. Pl.: 945.

= Spiranthes autumnalis (Balb.) Rich. (Lipsky, 1899).

Distribution, occurrence and habitats in the study area. Spiranthes spiralis is absent in NS, and it is distributed sporadically in SS. The species is noted in low-herbal meadows, along the glades, abandoned gardens and roadsides on almost all ridges in the interfluve from River Psou to River Khobza. In addition, the species is found in the basins of the rivers Psezuapse, Svirskaya and Makopse. Populations with a high number of individuals (200-500 plants) were observed in the villages of Khleborob and Progress. There are clusters in parks and sanatoria in Sochi city centre (Averyanova, 2017b). There are specimens collected in the vicinity of Tuapse (MW).

41. Steveniella satyrioides (Spreng.) Schltr. 1918, Repert. Spec. Nov. Regni Veg. 15: 295 (Nevski, 1935; Flerov, 1938; Grossheim, 1940; Dubovic, 2005; Averyanov, 2006; Zernov, 2006; Vakhrameeva et al., 2014; Litvinskaya, 2017; Ivanov, 2019; Litvinskaya, 2019).

三 Himantoglossum satyrioides Spreng. 1826, Syst. Veg. 3: 694.

$\equiv$ Platanthera satyroides Rchb. f. ex Lipsky (Lipsky, 1899).

Distribution, occurrence and habitats in the study area. This species is distributed all along the Black Sea coast of Krasnodarsky Krai: NS (quite rare), occurs solitary or in small groups (Zernov, 2000; Litvinskaya, 2017; Popovich, 2019a). The only large population was found on an abandoned agricultural land in the vicinity of the village Natukhaevskaya in 2019. It harboured at least 228 individuals per $100 \mathrm{~m}^{2}$. Steveniella satyrioides is sporadically spread across all forest communities in SS. There are usually $2-4$ individuals at the localities. Occasionally there are clusters of $20-40$ or more individuals. In the vicinity of the village Vorontsovka, in the upper reaches of the River Vostochnaya Khosta, the number varied from 18 individuals to 96 individuals per $620 \mathrm{~m}^{2}$ in different years. The species has a wide tolerance range to humidity and illumination conditions. It is observed in clearings in juniper (Juniperus deltoides), oakhornbeam (Quercus pubescens, Carpinus orientalis) and hornbeam (Carpinus betulus) forests in communities of petrophyte-steppe vegetation, in meadows, in the ecotone zone, in various forest communities. 


\section{Hybrids}

1. Anacamptis morio subsp. caucasica (K. Koch) H. Kretzschmar, Eccarius \& H. Dietr. $\times$ A. pyramidalis (L.) Rich.

Distribution, occurrence and habitats in the study area. This rare hybrid, known under the name Anacamptis $\times$ laniccae (Braun-Blanq.) $\mathrm{H}$. Kretzschmar, Eccarius \& H. Dietr. 2007, Orchid Gen. Anacamptis Orchis Neotinea 430 (described as the hybrid of «Anacamptis morio (L.) R.M. Bateman, Pridgeon \& M.W. Chase $\times A$. pyramidalis (L.) Rich.»), has been recorded once in NS, on the Kotsehur ridge (Plantarium, 2020).

2. Neotinea $\times$ dietrichiana (Bogenh.) $\mathrm{H}$. Kretzschmar, Eccarius \& H. Dietr. 2007, Orchid Gen. Anacamptis Orchis Neotinea 464 (described as hybrid of «Neotinea tridentata (Scop.) R.M. Bateman, Pridgeon $\&$ M.W. Chase $\times N$. ustulata (L.) R.M. Bateman, Pridgeon \& M.W. Chase») (Litvinskaya, 2019).

$\equiv$ Orchis $\times$ dietrichiana Bogenh. 1850, Taschenb. Fl. Jena 351 (described as hybrid of «Orchis tridentata Scop. $\times$ O. ustulata L.»).

Distribution, occurrence and habitats in the study area. This rare hybrid was recorded once in NS, on the Markotkh ridge (Plantarium, 2020).

3. Ophrys mammosa subsp. caucasica (Woronow ex Grossh.) Soó $\times O$. oestrifera M. Bieb.

Distribution, occurrence and habitats in the study area. This hybrid was noted in NS: Abrau peninsula, in the vicinity of Bolshoy Utrish and of Sukko (Personal communication: Logvinenko), the Markotkh ridge and Schel Tserkovnaya, in the vicinity of the village Svetluy.

Note. This hybrid is very variable in the structure of flowers. Some plants deviate to Ophrys mammosa subsp. caucasica, others to $O$. oestrifera. The length of the lateral lobes of the lip and the pattern of the lips, the length and colour of the inner tepals are especially variable.

4. Ophrys $\times$ vallis-costae Kümpel, 1988, Ber. Arbeitskr. Heim. Orch. 5(1-2): 27 (described as hybrid of «Ophrys apifera Huds. $\times O$. oestrifera subsp. abchasica Kümpel»).

Distribution, occurrence and habitats in the study area. This hybrid is known from a single type specimen from the Krasnodarsky Krai in the SS (Kümpel, 1988). In addition, the hybrid was recorded in Azerbaijan (Baumann et al., 2003) and Crimea (Fateryga et al., 2018a).

5. Orchis $\times$ angusticruris nothosubsp. transcaucasica B. Baumann, H. Baumann, R. Lorenz \& Ruedi Peter, 2003, J. Eur. Orch. 35(1): 194 (described as hybrid of «Orchis simia Lam. $\times$ O. purpurea subsp. caucasica (Regel) B. Baumann, H. Baumann, R. Lorenz \& Ruedi Peter»).

Distribution, occurrence and habitats in the study area. We know locations of this hybrid in NS, like in Anapa, in the vicinity of the village Supsekh (Plantarium, 2020); Gelendzhik, vicinity of the village Svetluy (Personal communication: Khoteev); Anapa, vicinity of the village Varvarovka, and on Shkolnaya mount in the vicinity of Tuapse.

6. Orchis $\times$ beyrichii nothosubsp mackaensis (Kreutz) Fateryga \& Kreutz, 2014, J. Eur. Orch. 46(2): 419 (described as hybrid of «Orchis militaris subsp. stevenii (Rchb. f.) B. Baumann, H. Baumann, R. Lorenz \& Ruedi Peter $\times$ O. simia Lam.»).

$\equiv$ O. $\times$ mackaensis Kreutz, 1989, Orchideeën 51(3): 72 (described as hybrid of «Orchis simia Lam. $\times$ O. stevenii Rchb. f.»).

Distribution, occurrence and habitats in the study area. This rare hybrid was noted in NS, in the vicinity of the village Raevskaya (Plantarium, 2020), vicinity of Gelendzhik (Personal communication: Khoteev), and on Shkolnaya mount near Dzhubga.

7. Orchis $\times$ calliantha Renz \& Taubenheim, 1983, Orchidee (Hamburg) 34(3): 95 (described as hybrid of «Orchis punctulata Steven ex Lindl. $\times O$. simia Lam.»).

Distribution, occurrence and habitats in the study area. We know locations of this hybrid from NS: Anapa, in the vicinity of the village Varvarovka (Plantarium, 2020; Personal communication: Gladkova); Novorossiysk, vicinity of the village Myshako (Popovich, 2018); Gelendzhik, vicinitys of the villages Svetluy and Bzhid.

8. Orchis $\times$ penzigiana A. Camus, 1928, Iconogr. Orchid. Europe 270 (described as hybrid of «Orchis mascula (L.) L. $\times$ O. provincialis Balb. ex Lam. \& DC.»).

Distribution, occurrence and habitats in the study area. This hybrid is common only in SS. It is mostly found together with its parental species in the colchian mixed and beech-hornbeam (Fagus orientalis, Carpinus betulus) forests in the Khosta River basin and Kudepsta River basin, solitary plants were found on Bytkha mount and in the vicinity of the village Vasilyevka. The ratio of the number of hybrids and individuals of parental taxa in some years reached 1:30.

Note. Orchis $\times$ colemani Cortesi, 1907, Ann. Bot. (Rome) 5: 540 (described as hybrid of «Orchis mascula (L.) L. $\times$ O. pauciflora Ten.») is erroneously noted on the Black Sea coast of Krasnodarsky Krai (Timukhin, 2010; Litvinskaya, 2017; 
Ivanov, 2019; Litvinskaya, 2019), since one of the parental taxa, $O$. pauciflora, does not occur in the Caucasus, as its range covers the Mediterranean region (Delforge, 2006). Orchis $\times$ penzigiana is usually characterised by a more powerful habitus, and an intermediate type of leaf colouration. The last trait is expressed in small, evenly allocated spots instead of large and dense spots typical for $O$. provincialis. At the same time, the spots on the leaves of $O . \times$ penzigiana are not concentrated on the leaf base or absent like in O. mascula. The hybrid is highly variable in the flower colouration: very bright flowers with a large number of spots are more common, but they are less often pale pink.

9. Orchis $\times$ wulffiana nothosubsp. suckowii (Kümpel) B. Baumann, H. Baumann, R. Lorenz \& Ruedi Peter, 2003, J. Eur. Orch. 35(1): 187 (described as hybrid of «Orchis purpurea subsp. caucasica (Regel) B. Baumann, H. Baumann, R. Lorenz $\&$ Ruedi Peter $\times O$. punctulata Steven ex Lindl.»).

$\equiv$ O. $\times$ suckowii Kümpel, 1988, Feddes Repert. 99(3-4): 94.

Distribution, occurrence and habitats in the study area. Solitary plants of this hybrid were noticed at four locations (along the rivers Sochi, Matsesta, and Khosta) in SS. This hybrid forms populations commonly characterised by quite a high number of individuals in NS. For example, a population of more than a hundred individuals flourishes in the presence of both parental species in abandoned vineyards in Anapa in the vicinity of the village Varvarovka. Apparently, its distribution along the Black Sea coast of Krasnodarsky Krai is directly related to the decrease in the number of Orchis punctulata from the north-west to the south-east.

Note. Orchis $\times$ wulffiana Soó is given for the Black Sea coast of Krasnodarsky Krai (Timukhin, 2010; Litvinskaya, 2017; Ivanov, 2019; Litvinskaya, 2019). However, O. purpurea subsp. purpurea is not distributed in the Caucasus. In this regard, we believe that it is correct to note the taxon $O . \times$ wulffiana nothosubsp. suckowii.

10. Platanthera $\times$ hybrida Brügger, 1880, Jahresber. Naturf. Ges. Graubündens II. xxiii-xxiv. 118 (described as hybrid of «Platanthera bifolia (L.) Rich. $\times$ P. chlorantha (Custer) Rchb.»).

Distribution, occurrence and habitats in the study area. This hybrid was noted in NS. It is more common than Platanthera bifolia, but less than $P$. chlorantha. It is confined to more arid habitats than P. bifolia.
Perhaps, other hybrids will be found on the Black Sea coast of Krasnodarsky Krai. For example, we know large populations of the two following pairs of co-occurring taxa: Anacamptis laxiflora subsp. dielseana and A. pyramidalis; Dactylorhiza romana subsp. georgica and D. urvilleana (Fig. 19S, Fig. 20S).

\section{Extinct taxa and erroneous indications}

1. Anacamptis coriophora (L.) R.M. Bateman, Pridgeon \& M.W. Chase (Dubovic, 2005; Zernov, 2006; Averyanov, 2006; Litvinskaya, 2019).

Note. Anacamptis coriophora is known on the basis of specimens, collected by Lipsky late XIX century and by Novopokrovsky early XX century (Zernov, 2000). We have not found these herbarium specimens. But there are some doubts about the correctness of their identification. In particular, in the collection of Novopokrovsky, the species is noted in an untypical habitat, «stony slope», while $A$. coriophora is confined to wet meadows and the banks of fresh water bodies. In the Tuapse-Adler district (SS), the species was noted by Timukhin (2003) along the middle course of the River Mzymta. This location is not included in the boundaries of the studied low-mountain part of this area. Due to the lack of currently reliable localities of this species, we have excluded it from the flora of the foothills and low mountains of the Black Sea coast of Krasnodarsky Krai. The species may have disappeared due to habitat destruction.

2. Dactylorhiza incarnata (L.) Soó (Flerov \& Flerov, 1926; Flerov, 1938; Dubovic, 2005).

Note. There is one old indication of this species in NS without confirmation by herbarium specimens (Flerov \& Flerov, 1926). Current studies did not confirm Dactylorhiza incarnata on the Black Sea coast of Krasnodarsky Krai (Solodko \& Makarova, 2011; Suslova et al., 2015; Popovich, 2019a).

3. Epipactis atrorubens (Hoffm.) Besser (Lipsky, 1899; Grossheim, 1940; Dubovic, 2005; Averyanov, 2006; Zernov, 2006; Vakhrameeva et al., 2014; Ivanov, 2019; Litvinskaya, 2019).

Note. Epipactis atrorubens is absent (Efimov, 2008; Fateryga \& Fateryga, 2018; Efimov, 2020) on the Black Sea coast of Krasnodarsky Krai and in the Russian Caucasus in general.

4. Epipactis palustris (L.) Crantz (Flerov \& Flerov, 1926; Flerov, 1938; Dubovic, 2005; Zernov, 2006; Litvinskaya, 2017; Ivanov, 2019; Litvinskaya, 2019).

Note. There is one old indication of this species in NS without confirmation by herbarium 
specimens (Flerov \& Flerov, 1926). Current research did not confirm E. palustris in the foothills and the low-mountains of the Black Sea coast of Krasnodarsky Krai. The species may have disappeared due to habitat destruction.

The following orchid species are found only in the mid-mountain and high-mountain parts of the Black Sea coast of Krasnodarsky Krai: Anacamptis coriophora (L.) R.M. Bateman, Pridgeon \& M.W. Chase, Corallorhiza trifida Châtel., Dactylorhiza euxina (Nevski) Czerep., Epipactis palustris (L.) Crantz, Epipogium aphyllum (F.W. Schmidt) Sw., Goodyera repens (L.) R. Br., Neottia cordata (L.) Rich., Orchis pallens L., O. spitzelii Saut. ex W.D.J. Koch, Traunsteinera globosa (L.) Rchb., and T. sphaerica (M. Bieb.) Schltr. The mid-mountain and high-mountain areas were not included in this study.

\section{Habitats}

The association of orchids with plant communities is shown in Electronic Supplement 2. Almost all species are more or less strictly confined to forest communities. The exceptions are eight taxa recorded only in herbaceous communities and rarely shrubs: Anacamptis laxiflora, A. morio subsp. caucasica, Dactylorhiza viridis, Gymnadenia conopsea, Himantoglossum caprinum, Neotinea ustulata, Serapias orientalis subsp. feldwegiana, and Spiranthes spiralis (Electronic Supplement 2). Thirteen taxa are confined to herbaceous plant communities and ecotone habitats, less frequently observed in forest communities, mainly on the borders and in light forests. For example, Anacamptis laxiflora subsp. dielseana, a species confined to swampy meadows, is rarely observed in floodplain forest communities, dominated by Fraxinus excelsior or in the mass young tree and shrub vegetation in floodplain waterlogged areas. In the case of overgrowth of meadows and partially steppe communities, some orchids are able to exist under modified conditions for a certain period. Under such conditions, the density and number of individuals in populations become lower than in herbaceous plant communities. In addition, negative conditions appear for seed production of orchids. In forest communities, it is expressed predominantly in a decrease in pollinator activity. In Himantoglossum caprinum, confined to ecotone habitats, flowers and fruits are damaged by parasitic ascomycetes in shady forest communities. This fact almost completely excludes the seed production (Popovich, 2017, 2019b). Anacamptis morio subsp. caucasica and Neotinea tridentata are confined to dry meadows and steppe communities, less frequently observed in shrub communities of the ecotone belt and in sparse juniper (Juniperus excelsa, J. foetidissima, J. deltoides) communities, avoiding strong shading. Anacamptis pyramidalis, Ophrys apifera, O. mammosa subsp. caucasica, Orchis militaris subsp. stevenii, O. punctulata, and $O$. simia are confined to xerophilic and mesoxerophilic deciduous shrub thickets and sparse juniper (Juniperus excelsa, J. foetidissima, J. deltoides) communities. But they could grow on both gravelly slopes as part of petrophyte vegetation as well as under conditions of some shading in oak (Quercus pubescens, $Q$. petraea) forests. Twenty-one taxa are associated with forest communities (Electronic Supplement 2). They include Dactylorhiza urvilleana, Himantoglossum comperianum, Limodorum abortivum, Orchis provincialis, Platanthera bifolia, all species of the genera Cephalanthera and Epipactis, and Neottia. We emphasise that Cephalanthera epipactoides is confined to light, mainly coastal pine (Pinus brutia var. pityusa) forests, It is observed in sparse communities of xerophilic and mesoxerophilic deciduous shrub thickets, as well as in herbaceous communities.

Dactylorhiza romana subsp. georgica, Ophrys oestrifera, Orchis mascula, O. purpurea subsp. caucasica, Platanthera chlorantha, and Steveniella satyrioides have a wide range of habitat tolerance. They can be represented equally in both forest and herbaceous plant communities with different moisture levels. For example, Steveniella satyrioides was observed on the edges of coastal talus slopes, in meadow communities, in woodland clearings, shrub thickets in the ecotone, on abandoned agricultural lands, as well as in oak (Quercus petraea), hornbeam and beechhornbeam (Carpinus betulus, Fagus orientalis) forests. Dactylorhiza romana subsp. georgica is equally noted in mountain meadows, oak (Quercus petraea), beech (Fagus orientalis), and hornbeam (Carpinus betulus) forests.

Favourable conditions of 19 taxa exist in anthropogenic habitats, preferring sides of forest roads, power lines, abandoned agricultural lands, hay meadows and even dendroparks. On such places, competitive relationships with other plants are reduced. In such habitats, some taxa form large populations. For example, in abandoned fields and vineyards, Anacamptis morio subsp. caucasica, Orchis punctulata, and $O$. simia can form local populations represented by numerous individuals (Fig. 17S, Fig. $18 \mathrm{~S})$. Spiranthes spiralis is mainly confined to pitting meadows, abandoned gardens, and roadsides. 


\section{Conservation issues for rare orchid species}

The Red Data Book of the Russian Federation (2008) includes 66 orchid species, including 27 species distributed on the Black Sea coast of Krasnodarsky Krai. Six species have the highest category of rarity status (Table), four species have category 2 (declining in numbers), 14 species have category 3 (rare species). The Red Data Book of Krasnodarsky Krai (Litvinskaya, 2017) includes 45 taxa. Of them, 34 orchid taxa are distributed on the Black Sea coast of Krasnodarsky Krai, including two hybrids. Five taxa are classified as Critically Endangered; nine taxa are Endangered; 20 taxa are Vulnerable. On the basis of our long-term studies, we identified IUCN Red List categories for each orchid taxon in the study area (Table). In accordance with the IUCN Standards and Petitions Committee (2019), we did not evaluate hybrid taxa according to the IUCN Red List criteria and did not assign them a threatened taxon category.

Seven taxa have the highest taxon extinction threat category on the Black Sea coast of the Krasnodarsky Krai (Table). Two species (Dactylorhiza viridis, Neotinea ustulata) have an extensive range in Russia (Efimov, 2020). But they are exceedingly rare in the study area due to the ecological features of habitats, which limit their distribution.

Monitoring studies have shown that on the Black Sea coast of Krasnodarsky Krai, three known Anacamptis laxiflora subsp. dielseana populations, located near settlements, are in a critical condition (Popovich, 2019a,b). This is caused by the complex action of adverse biotic and anthropogenic factors, including habitat succession, overgrowth of swampy meadows with woody and shrubby vegetation, including invasive trees and shrubs (e.g. Ailanthus altissima (Mill.) Swingle, Elaeagnus angustifolia L., Spartium junceum L.), drainage and destruction of habitats during construction. If we do not exclude the effect of these limiting factors, we predict that after ten years, the number of $A$. laxiflora subsp. dielseana may have decreased by more than $80 \%$.

Ophrys apifera has a higher range of tolerance to environmental factors than A. laxiflora subsp. dielseana, but it is also a very rare and threatened orchid. Most of the relatively large populations are situated near or into settlements, which causes a high risk for extinction. For example, in 2017 in SS a large $O$. apifera population was severely affected on mount Lysaya near the village Vardane (SS) due to the plowing of this area. Hence, its complete destruction is possible. In addition, in 2019, $20 \%$ of the largest $O$. apifera population in NS was destroyed as a result of land clearing near the Protected Area «Prilagunye».

In Russia, the range of Cephalanthera epipactoides is limited by a narrow strip along the Black Sea coast of Krasnodarsky Krai (Fateryga et al., 2020). Most habitats of this species are under anthropogenic pressure due to the development of coastal areas for resort construction and recreation. In Russia, the risk of $C$. epipactoides extinction increases due to the drying out of buds and flowers due to adverse weather conditions (spring droughts), as well as a low fruit productivity. Epipactis condensata is extremely rare, too. Only in recent years, the information on the distribution of this species appeared in the study area of Krasnodarsky Krai. After analysing the existing herbarium materials and carrying out additional field studies, we came to the conclusion that $E$. condensata is in a critical condition. The known populations of the species are represented by a low number of individuals, while most of the locations are under a certain threat degree of extinction.

Epipactis euxina is confined to vulnerable coastal forest communities with the participation of Pinus brutia var. pityusa and Quercus pubescens. It is known from only one locality. Only this species is endemic for the Black Sea coast of Krasnodarsky Krai. For the first time E. euxina was found in the Protected Area «Roshcha sosny pitsundskoy "Dzhankhotskaya"» in 2017. The number of individuals was 36 in two subpopulations. In 2019, a new subpopulation with 48 individuals was noted. The total number of the entire population is 84 individuals. Due to the lack of knowledge of the new species, it is difficult to determine the threat category. However, Epipactis euxina is undoubtedly represented by a small number of individuals, and associated with narrow environment conditions, and, consequently, a small area of occupancy. We assume that E. euxina is restricted to the Black Sea coast of Krasnodarsky Krai. And its habitat area is so small that the risk of extinction is very high. It especially occurs under habitat degradation due to periodic emergencies (wildfires) and further erosion of coastal slopes, as well as due to a high recreational pressure, building construction, and infrastructure development. Therefore, we categorised this species as Critically Endangered.

Himantoglossum comperianum was known with several generative individuals from one location in SS. In recent years, its plants are not observed on this location. The species has probably disappeared from the Black Sea coast of Krasnodarsky Krai. 
Table. Orchid conservation status on the Black Sea coast of Krasnodarsky Krai (Russia)

\begin{tabular}{|c|c|c|c|}
\hline Taxa & $\begin{array}{l}\text { IUCN Red List category } \\
\text { in the study area }\end{array}$ & $\begin{array}{l}\text { Red Data Book of } \\
\text { Krasnodarsky Krai } \\
\text { (Litvinskaya, 2017) }\end{array}$ & $\begin{array}{c}\text { Red Data Book of the } \\
\text { Russian Federation (2008) }\end{array}$ \\
\hline Anacamptis laxiflora subsp. dielsiana & $\mathrm{CR}$ & $\mathrm{EN}^{2}$ & $1^{2}$ \\
\hline Anacamptis morio subsp. caucasica & VU & $\mathrm{EN}^{3}$ & $3^{3}$ \\
\hline Anacamptis pyramidalis & NT & VU & 3 \\
\hline Cephalanthera damasonium & NT & VU & 3 \\
\hline Cephalanthera epipactoides & $\mathrm{CR}$ & $\mathrm{CR}^{4}$ & $2^{12}$ \\
\hline Cephalanthera longifolia & VU & VU & 3 \\
\hline Cephalanthera rubra & NT & VU & 3 \\
\hline Dactylorhiza romana subsp. georgica & VU & $\mathrm{VU}^{5}$ & - \\
\hline Dactylorhiza urvilleana & VU & VU & 3 \\
\hline Dactylorhiza viridis & $\mathrm{CR}$ & - & - \\
\hline Epipactis condensata & $\mathrm{CR}$ & $\mathrm{CR}$ & - \\
\hline Epipactis euxina & $\mathrm{CR}$ & - & - \\
\hline Epipactis helleborine subsp. tremolsii & $\mathrm{LC}$ & - & - \\
\hline Epipactis krymmontana & DD & - & - \\
\hline Epipactis leptochila subsp. leptochila & DD & - & - \\
\hline Epipactis leptochila subsp. neglecta & DD & - & - \\
\hline Epipactis microphylla & VU & EN & - \\
\hline Epipactis muelleri & DD & - & - \\
\hline Epipactis persica & DD & - & - \\
\hline Epipactis pontica & VU & - & - \\
\hline Gymnadenia conopsea & VU & - & - \\
\hline Himantoglossum caprinum & EN & EN & 1 \\
\hline Himantoglossum comperianum & $\mathrm{CR}^{\mathrm{PRE}}$ & $\mathrm{CR}$ & - \\
\hline Limodorum abortivum & NT & VU & 3 \\
\hline Neotinea tridentata & NT & VU & $3^{13}$ \\
\hline Neotinea ustulata & $\mathrm{CR}$ & VU & $2^{14}$ \\
\hline Neottia nidus-avis & $\mathrm{LC}$ & - & - \\
\hline Neottia ovata & VU & $\mathrm{VU}^{6}$ & - \\
\hline Ophrys apifera & $\mathrm{CR}$ & EN & 1 \\
\hline Ophrys mammosa subsp. caucasica & EN & $\mathrm{EN}^{7}$ & $1^{7}$ \\
\hline Ophrys oestrifera & VU & VU & 2 \\
\hline Orchis mascula & NT & VU & 3 \\
\hline Orchis militaris subsp. stevenii & $\mathrm{EN}$ & $\mathrm{VU}^{8}$ & $3^{8}$ \\
\hline Orchis provincialis & VU & EN & 1 \\
\hline Orchis punctulata & NT & VU & 3 \\
\hline Orchis purpurea subsp. caucasica & VU & VU & 3 \\
\hline Orchis simia & VU & VU & 3 \\
\hline Platanthera bifolia & VU & VU & - \\
\hline Platanthera chlorantha & NT & VU & - \\
\hline Serapias orientalis subsp. feldwegiana & VU & $\mathrm{VU}^{8}$ & $2^{8}$ \\
\hline Spiranthes spiralis & VU & EN & 3 \\
\hline Steveniella satyrioides & VU & EN & 1 \\
\hline Anacamptis morio subsp. caucasica $\times$ A. pyramidalis & - & - & - \\
\hline Neotinea $\times$ dietrichiana & - & - & - \\
\hline Ophrys mammosa subsp. caucasica $\times$ O. oestrifera & - & - & - \\
\hline Ophrys $\times$ vallis-costae & - & - & - \\
\hline Orchis $\times$ angusticruris nothosubsp. transcaucasica & - & - & - \\
\hline Orchis $\times$ beyrichii nothosubsp. mackaensis & - & - & - \\
\hline Orchis $\times$ calliantha & - & - & - \\
\hline Orchis $\times$ penzigiana & - & $\mathrm{CR}^{10}$ & - \\
\hline Orchis $\times$ wulffiana nothosubsp. suckowii & - & $\mathrm{CR}^{11}$ & - \\
\hline Platanthera $\times$ hybrida & - & - & - \\
\hline
\end{tabular}

Note: IUCN Red List categories: CR - Critically Endangered; PRE - Possible Regional Extinct; EN - Endangered; VU - Vulnerable; NT

- Near Threatened; DD - Data Deficient. Designations: ${ }^{1}$ - IUCN Red List category of the regional populations of taxa in the study area;

${ }^{2}$ - as Orchis palustris Jacq.; ${ }^{3}$ - as O. picta Loisel.; ${ }^{4}$ - as Cephalanthera cucullata Boiss.; ${ }^{5}$ - as Dactylorhiza flavescens (C. Koch) Holub;

${ }^{6}$ - as Listera ovata (L.) R. Br.; ${ }^{7}$ - as Ophrys caucasica Woronow ex Grossh.; ${ }^{8}$ - as Orchis militaris L.; ${ }^{9}$ - as Serapias vomeracea (Burm.

f.) Briq.; ${ }^{10}$ - as Orchis colemanii Cortesi; ${ }^{11}$ - as O. wulffiana Soó; ${ }^{12}$ - as Cephalanthera floribunda Woronow; ${ }^{13}$ - as Orchis tridentata

Scop.; ${ }^{14}$ - as O. ustulata L. 
Special attention should be paid to taxa having the category Endangered. In NS, Himantoglossum caprinum has several quite dense populations with numerous individuals, the loss of which will raise the taxon's threat category to a critical one. In particular, there is a high threat of loss of the population in the vicinity of the village Verkhnebakansky. In Krasnodarsky Krai and the Russian Caucasus as a whole, this population is the richest in terms of number of individuals, although its location borders to the industrial zone of the village. Ophrys mammosa subsp. caucasica and Orchis militaris subsp. stevenii have a natural rarity. They are confined to places, attractive for resort construction and agricultural development. Therefore, the risk of reducing their populations to a critical level is extremely high.

Insufficient data on some Epipactis taxa does not allow us to give an accurate estimation of the size and status of their populations caused by their natural rarity (Table). Epipactis krymmontana, E. leptochila, E. muelleri, and E. persica are known from one or more locations represented by several generative individuals or small groups. We believe that with more detailed and targeted studies, their regional distribution will not be limited to the Black Sea coast of Krasnodarsky Krai. A positive aspect, that gives hope for the conservation of Epipactis species new for the Black Sea coast of Krasnodarsky Krai, is their association with forest communities, mainly beech (Fagus orientalis) and hornbeam (Carpinus betulus)forests, which cover a considerable part of the study area. An exception is the subendemic species E. krymmontana, which is confined, like E. euxina, to the coastal pine (Pinus brutia var. pityusa) forests.

For some orchid species, moderate anthropogenic pressure can induce an increase in the number and density of individuals in populations, by reducing competition from other plant species. Such an influence could be the thinning of the woody vegetation or a decrease in the density and height of the herb layer. It forms the favourable conditions for some orchid taxa associated with meadows and forest edges (e.g. Anacamptis morio subsp. caucasica, Neotinea tridentata, Ophrys apifera, Orchis punctulata, O. simia, Serapias orientalis subsp. feldwegiana, and Spiranthes spiralis). Therefore, some species form large populations on abandoned agricultural lands, pastures and hayfields. In such habitats, regulation of economic activity and constant monitoring of the conditions of orchid populations (especially large ones) will allow some taxa to be preserved.

The control of invasive plant species is of great importance for conservation of orchid populations.
This especially concerns the invasion of woody plants, which rapidly modify the conditions of orchid habitats. Due to the climate change, invasion of alien species could be increased. Therefore, decisive measures must be taken to limit their distribution.

To preserve species associated with climax plant communities, it is necessary to create Protected Areas with a strict protection regime. The organisation of Protected Areas is necessary to protect key habitats and threatened ecosystems associated with ecotones and the rapidly changing plant communities. Their positive effects concern either restriction of human influence by slowing down succession processes, or development of measures to reduce the overgrowth rate in herbaceous communities and for mandatory monitoring of the status of orchid populations on these sites. These conditions must be specified in the regulations for each Protected Area, which is responsible for conservation of rare orchid species. In our opinion, on the Black Sea coast of Krasnodarsky Krai, the most optimal Protected Area types for the rare species protection seem to be national parks and regional natural parks, which should have a larger area. This protection regime will preserve valuable natural complexes from destruction. On the other hand, in the study area, it will allow establishing sustainable development of eco-tourism and reduce the risks of conflicts between environmental authorities, local residents and business. It is the best way to create regional-level nature monuments and municipal Protected Areas having an optimal protection regime for small natural complexes on the Black Sea coast of Krasnodarsky Krai, especially those, located near or within settlements boundaries.

Thus, we believe that the most effective way to protect orchid populations in the study region is the further development of a Protected Areas network, primarily through the creation of regional (nature parks, nature monuments) and municipal Protected Areas. Although in SS orchids are well preserved in the Sochi National Park, in NS, key habitats of orchids are insufficiently protected. Only in the Utrish State Nature Reserve, populations of 22 species are protected. But most of them are extremely small in this Protected Area (Timukhin, 2017). In this regard, the urgent question concerns the early creation of the Markotkh Nature Park. There are populations of 28 orchid species within an area of more than $650 \mathrm{~km}^{2}$ (Markotkh Nature Park project documentation, 2019) the necessity of its creation was justified by leading experts in 2017. At the regional level, it is also necessary to protect the key habitats of orchids on Shkolnaya mount, Vardane mount, the Verhnebakanskaya $\mathrm{Hi}$ - 
mantoglossum caprinum population, the remains of floodplain ash (Fraxinus excelsior) and oak (Quercus robur) forests in the vicinity of the village Raevskaya, swampy meadows on cape Tonkiy in Gelendzhik, the floodplain of the stream near the Sukko reservoir, coastal pine (Pinus brutia var. pityusa) forests on the Tuaphat ridge, and the coastal area of Betta - cape Idokopas. It is necessary to clarify the new borders of the Abrau Sanctuary and Agri Sanctuary.

Compensation methods are traditionally used in the implementation of economic activity in undisturbed natural areas, in particular, translocation (transplanting). But actually they do not work for orchids, which leads to their extinction. Therefore, habitats of orchids, involved in human activity, disappear completely without appearing anywhere else. Perhaps, it makes sense to create a nursery at specialised educational, scientific or environmental institutions, which will be constantly engaged in the orchid restoration in Protected Areas.

\section{Conclusions}

Taking into consideration the current taxonomic and nomenclature re-evaluation, 52 taxa (41 species, eleven subspecies) and ten hybrids of Orchidaceae are reliably known within the borders of the foothills and low mountains on the Black Sea coast of Krasnodarsky Krai. Five of these taxa are not found anywhere else in Russia, including Cephalanthera epipactoides, Epipactis euxina, E. leptochila subsp. neglecta, E. pontica, and Serapias orientalis subsp. feldwegiana. Two taxa, namely Epipactis condensata and Ophrys mammosa subsp. caucasica, slightly exceed the boundaries of the study area.

We obtained data on new locations and the size of populations of threatened orchid taxa. In 2019, we found large populations of Anacamptis morio subsp. caucasica, Dactylorhiza romana subsp. georgica, and Steveniella satyrioides. We found the currently northernmost Cephalanthera epipactoides location, new locations of Epipactis leptochila subsp. leptochila, E. muelleri, E. pontica, Ophrys apifera, O. mammosa subsp. caucasica, and Orchis militaris subsp. stevenii.

Current research could not confirm the distribution of Anacamptis coriophora, Dactylorhiza incarnata, and E. palustris in the foothills and the low-mountain of the Black Sea coast of Krasnodarsky Krai. These species may have disappeared due to habitat destruction.

Eleven taxa are represented by an extremely low number of both populations and individuals per population. Further strengthening of the limitation and the occurrence of emergencies may lead to their disappearance in the study area. Therefore, it is necessary to develop measures to protect and maintain such populations of threatened taxa.

The development of a Protected Areas network, covering the most valuable and threatened ecosystems on the Black Sea coast of Krasnodarsky Krai is a top priority in biodiversity conservation, including orchids.

Information on the number, habitat and other population characteristics of five taxa is so small, that it is impossible to accurately assess the status of their populations. In this regard, more research is needed to find new locations of taxa and conduct environmental and biological studies of already known populations.

We want to draw attention to another problem, the unifying volumes of taxa in various environmental documents, which is crucial for their effective protection. The existing contradictions in Red Data Books and other legal documents in terms of orchid taxonomy make it difficult for conservation-based organisations and the development of measures to counteract the extinction of threatened taxa. It is long overdue to reissue the Red Data Book of the Russian Federation (2008). Twelve years after its publication, a vast amount of new data has been accumulated, including the status of populations of threatened orchids in Russia.

\section{Acknowledgments}

We thank Alexander V. Fateryga for help in the manuscript editing and Tatyana A. Grigorieva for translating the paper. The reported study was funded by the Russian Geographical Society according to the research project «Protected Natural Areas and the Conservation of the Biological Diversity of the Russian Caucasus» (№ 37/2020-P).

\section{Supporting Information}

Photographs of selected orchid species known on the Black Sea coast of Krasnodarsky Krai (Electronic Supplement 1: The rarest orchid taxa on the Black Sea coast of Krasnodarsky Krai), and a character of orchid association with plant communities in the study area (Electronic Supplement 2: The association of orchid taxa with plant communities on the Black Sea coast of Krasnodarsky Krai) may be found in the Supporting Information here.

\section{References}

Akhalkatsi M., Kimeridze M., Künkele S., Lorenz R., Mosulishvili M. 2003. Diversity and conservation of Georgian orchids. Tbilisi: CGS Ltd. $40 \mathrm{p}$.

Ataev Z.V., Bratkov V.V. 2009. The modern problems of protection of biological and landscape diversity of 
the Northern Caucasus ecological region. South of Russia: ecology, development 4(4): 215-222. DOI: 10.18470/1992-1098-2009-4-215-222 [In Russian]

Averyanov L.V. 2006. Orchidaceae. In: A.L. Takhtadjan (Ed.) Ж Caucasian Flora Conspectus. Vol. 2. Saint Petersburg: Saint Petersburg University. P. 84-101. [In Russian]

Averyanov L.V., Nersesyan A.A. 2001. Orchidaceae. In: E.Ts. Gabrielyan, M.E. Oganessian (Eds.): Flora of Armenia. Vol. 10. Liechtenstein, Ruggel: A.R.G. Gantner Varlag KG. P. 165-225. [In Russian]

Averyanova E.A. 2013. Epipactis pontica Taubenheim - new species for the flora of Russia. Turczaninowia 16(3): 38 43. DOI: 10.14258/turczaninowia.16.3.7 [In Russian]

Averyanova E.A. 2015. Features of biology and ecology of Ophrys oestrifera Bieb. (Orchidaceae) in the Sochi Black Sea coast. In: Problems of Botany in Southern Siberia and Mongolia. Barnaul: Altai State University. P. 240-249. [In Russian]

Averyanova E.A. 2016. Features of the biology of the rare species Orchis picta Loisel. (Orchidaceae) in the Sochi Black Sea coast. In: Problems of Botany in Southern Siberia and Mongolia. Barnaul: Altai State University. P. 207-211. [In Russian]

Averyanova E. A. 2017a. Features of the biology of Ophrys apifera Huds. (Orchidaceae) in the Sochi Black Sea coast. In: Problems of Botany in Southern Siberia and Mongolia. Barnaul: Concept. P. 101-105. [In Russian]

Averyanova E.A. 2017b. Features of the biology and distribution of Spiranthes spiralis (L.) Cheval. in the Sochi Black Sea Region (Western Transcaucasia). Bulletin of Moscow Society of Naturalists 122(5): 65-75. [In Russian]

Averyanova E.A. 2018a. Biological Features of Anacamptis pyramidalis (L.) Rich. (Orchidaceae) in the Sochi Black Sea Region (Western Transcaucasia). In: Problems of Botany in Southern Siberia and Mongolia. Barnaul: Altai State University. P. 176-179. [In Russian]

Averyanova E.A. 2018b. New locations of rare orchids (Orchidaceae) of the Sochi Black Sea coast. In: L.M. Shagarov (Ed.): Sustainable development of Protected Areas. Vol. 6. Sochi: Natural ornithological park in the Imeretinskaya lowland. P. 38-43. [In Russian]

Averyanova E.A. 2019a. Population dynamics, distribution and biology features of Dactylorhiza urvilleana (Orchidaceae) in the Sochi Black Sea coast. In: Problems of Botany in Southern Siberia and Mongolia. Barnaul: Altai State University. P. 80-85. [In Russian]

Averyanova E.A. 2019b. To the definition of Serapias feldwegiana H. Baumann \& Künkele (Orchidaceae) in the Sochi Black Sea region. Botanical Herald of the North Caucasus 1: 7-13. [In Russian]

Bateman R.M., Molnár A.V., Sramkó G. 2017. In situ morphometric survey elucidates the evolutionary systematics of the Eurasian Himantoglossum clade (Orchidaceae: Orchidinae). PeerJ 5: e2893. DOI: 10.7717/peerj.2893

Bateman R.M., Rudall P.J. 2018. Clarified relationship between Dactylorhiza viridis and Dactylorhiza iberica renders obsolete the former genus Coeloglossum (Orchidaceae: Orchidinae). Kew Bulletin 73(4): 4. DOI: $10.1007 / \mathrm{s} 12225-017-9728-\mathrm{Z}$
Baumann B., Baumann H., Lorenz R., Peter R. 2003. Beitrage zur Orchideenflora des östlichen Transkaukasus und Talysch (Aserbaidschan). Journal Europäischer Orchideen 35(1): 163-231.

Belyuchenko I.S. 2005. Ecology of the Kuban. Krasnodar: Kuban State Agricultural University. 513 p. [In Russian]

Bohn U., Gollub G., Hettwer C., Neuhäuslova Z., Raus Th., Schlüter H., Weber H. 2004. Map of the Natural Vegetation of Europe. Scale 1:2 500 000. Bonn. 525 p.

Chase M.W., Cameron K.M., Barrett R.L., Freudenstein J.V. 2003. DNS data and Orchidaceae systematics: a new phylogenic classification. In: K.W. Dixon, S.P. Kell, R.L. Barrett, P.J. Cribb (Eds.): Orchid conservation. Kota Kinabalu: Sabah, Natural History Publications. P. 69-89.

Chase M.W., Cameron K.M., Freudenstein J.V., Pridgeon A.M., Salazar G., van den Berg C., Schuiteman A. 2015. An updated classification of Orchidaceae. Botanical Journal of the Linnean Society 177(2): 151-174. DOI: 10.1111/boj.12234

Chernovol V.P. 2006. Orchids of the Tuapse district. Tuapse: Shaban. 56 p. [In Russian]

Christenhusz M.J.M., Byng J.W. 2016. The number of known plants species in the world and its annual increase. Phytotaxa 261(3): 201-217. DOI: 10.11646/ phytotaxa.261.3.1

Delforge P. 1999. Contribution taxonomique et nomenclaturale au genere Himantoglossum (Orchidaceae). Naturalistes Belges 80: 387-408.

Delforge P. 2006. Orchids of Europe, North Africa and the Middle East. London: A. \& C. Black. 640 p.

Demina O.N., Ogureeva G.N., Rogal L.L., Bocharnikov M.V., Dmitriev P.A. 2015a. Coenotic diversity and syntaxonomy of xerophytic coniferous and woodlands in the Utrish State Nature Reserve. In: O.N. Bykhalova (Ed.): Biota conservation in the Utrish State Nature Reserve. Vol. 3. Maykop: Poligraf-YUG» P. 80-106. [In Russian]

Demina O.N., Rogal L.L., Suslova E.G., Dmitriev P.A., Kozhin M.N., Seregin A.P., Bykhalova O.N. 2015b. Synopsis of the flora of the State Nature Reserve Utrish. Zhivye $i$ biokosnye sistemy 13. Available from https://www.jbks.ru/ archive/issue-13/article-8 [In Russian]

Dubovic O.N. 2005. Florogeneses of the Crimean-Neorossicus Province. Kiev: Fyton. 180 p. [In Russian]

Efimov P.G. 2008. Notes on Epipactis condensata, E. rechingeri and E. purpurata (Orchidaceae) in the Caucasus and Crimea. Willdenowia 38(1): 71-80. DOI: 10.3372/wi.38.38104

Efimov P.G. 2020. Orchids of Russia: annotated checklist and geographic distribution. Nature Conservation Research 5(Suppl.1): 1-18. DOI: 10.24189/ncr.2020.018

Fateryga A.V., Efimov P.G., Fateryga V.V. 2018a. Taxonomic notes on the genus Ophrys L. (Orchidaceae) in the Crimea and the North Caucasus. Turczaninowia 21(4): 9-18. DOI: 10.14258/turczaninowia.21.4.2

Fateryga A.V., Efimov P.G., Svirin S.A. 2019. Orchids of the Crimean Peninsula. Simferopol: Arial. 224 p. [In Russian]

Fateryga A.V., Fateryga V.V. 2018. The genus Epipactis Zinn (Orchidaceae) in the flora of Russia. Turczaninowia 21(4): 19-34. DOI: 10.14258/turczaninowia.21.4.2 [In Russian]

Fateryga A.V., Kreutz C.A.J., Fateryga V.V., Efimov P.G. 2014. Epipactis krymmontana (Orchidaceae), a new species endemic to the Crimean Mountains and notes on the related 
taxa in the Crimea and bordering Russian Caucasus. Phytotaxa 172(1): 22-30. DOI: 10.11646/phytotaxa.172.1.3

Fateryga A.V., Popovich A.V., Fateryga V.V., Averyanova E.A., Kreutz C.A.J. 2018b. New data on the genus Epipactis (Orchidaceae) in the North Caucasus with description of a new species. Phytotaxa 358(3): 278-288. DOI: 10.11646/phytotaxa.358.3.5

Fateryga A.V., Popovich A.V., Fateryga V.V., Kreutz C.A.J. 2020. Cephalanthera epipactoides (Orchidaceae) in Russia. Nature Conservation Research 5 (Suppl.1): 69-76. DOI: $10.24189 /$ ncr.2020.014

Fay M.F. 2018. Orchid conservation: how can we meet the challenges in the twenty-first century? Botanical Studies 59(1): 16. DOI: $10.1186 / \mathrm{s} 40529-018-0232-\mathrm{z}$

Flanagan N.S., Peakall R., Clements M.A., Otero J.T. 2006. Conservation of taxonomically difficult species: the case of the Australian orchid, Microtis angusii. Conservation Genetics 7(6): 847-859. DOI: 10.1007/s10592-006-9119-8

Flerov A.F., Flerov V.A. 1926. Vegetation of the North Black Sea coast of the Caucasus. 1. Vegetation of the Abrau Peninsula and the coast of Anapa-Novorossiysk. Proceedings of North Caucasus Association of scientificresearch institutes 8: 1-94. [In Russian]

Flerov A.F. 1938. List of plants of the North Caucasus and Dagestan. Rostov-on-Don. 696 p. [In Russian]

Fomin A.V., Woronow G.N. 1909. Key to plants of the Caucasus and the Crimea. Vol. 1. Tiflis. 340 p. [In Russian]

Gale S.W., Fischer G.A., Cribb P.J., Fay M.F. 2018. Orchid conservation: bridging the gap between science and practice. Botanical Journal of the Linnean Society 186(4): 425-434. DOI: 10.1093/botlinnean/boy003

Govaerts R., Bernet P., Kratochvil K., Gerlach G., Carr G., Alrich P., Pridgeon A.M., Pfahl J., Campacci M.A., Holland Baptista D., Tigges H., Shaw J., Cribb P., George A., Kreutz K., Wood J. 2020. World Checklist of Orchidaceae. Kew: Royal Botanic Gardens. Available from http://apps.kew.org/wcsp

Grinevetsky B.B. 1916. Dioscoreaceae. In: N.I. Kuznetsov, N.A. Bush, A.V. Fomin (Eds.): Flora Caucasica Critica. Materials for the flora of the Caucasus. Yuriev. P. 18-32. [In Russian]

Grossheim A.A. 1940. Flora of the Caucasus. $2^{\text {nd }}$ ed. Vol. 2. Baku: Azerbaijanian Branch of the Academy of Sciences. 284 p. [In Russian]

Guzhin G.S. Nagalevsky Yu.A., Tyurin V.N. 1996. Atlas of the Krasnodarsky Krai and the Republic of Adygea. Minsk: Komitet Gosznak. 48 p. [In Russian]

Hollingsworth P.M., Squirrell J., Hollingsworth M.L., Richards A.J., Bateman R.M. 2006. Taxonomic complexity, conservation and recurrent origins of selfpollination in Epipactis (Orchidaceae). In: J. Bailey, R.G. Ellis (Eds.): Current taxonomic research on the British and European flora. London: Botanical Society of Britain and Ireland Press. P. 27-44.

iNaturalist. 2020. A community for Naturalists. Available from https://www.inaturalist.org/

IPNI. 2020. International Plant Names Index. Kew: Royal Botanic Gardens. Available from http://www.ipni.org

IUCN Standards and Petitions Committee. 2019. Guidelines for Using the IUCN Red List Categories and Criteria.
Version 14. Prepared by the Standards and Petitions Committee. Available from http://www.iucnredlist.org/ documents/RedListGuidelines.pdf

Ivanov A.L. 2019. Conspectus florae Caucasi Rossicae (plantae vasculares). Stavropol: North-Caucasus Federal University Press. 306 p. [In Russian]

Ivanov A.L., Kovaleva O.A. 2005. Orchids of the North Caucasus. Stavropol: Stavropol State University Press. 100 p. [In Russian]

Jin W.T., Schuiteman A., Chase M.W., Li J.W., Chung S.W., Hsu T.C., Jin X.H. 2017. Phylogenetics of subtribe Orchidinae s.l. (Orchidaceae; Orchidoideae) based on seven markers (plastid matK, psaB, rbcL, trnL-F, trnHpsba, and nuclear nrITS, Xdh): implications for generic delimitation. BMC Plant Biology 17(1): 222. DOI: 10.1186/s12870-017-1160-x

Kreutz C.A.J., Fateryga A.V., Ivanov S.P. 2018. Orchids of the Crimea. Sint Geertruid: Kreutz Publishers. 576 p.

Kuropatkin V.V., Efimov P.G. 2014. A review of the genera Anacamptis, Neotinea and Orchis s.str. (Orchidaceae) in the flora of Russia and adjacent countries, with considerations of subdivision of Orchis s.l. Botanicheskii Zhurnal 99(5): 555-593. [In Russian]

Kümpel H. 1988. Über neue Orchideen aus dem Gebiet des Schwarzmeer-Kaukasus. Berichte aus den Arbeitskreisen heimische Orchideen 5(1/2): 24-37.

Lipka O.N. 2009. Appendix L.1 - Flora Utrish State Nature Reserve. Ecological and economic justification for the formation of Utrish State Nature Reserve. Moscow: WWF. P. 131-190. [In Russian]

Lipsky V.I. 1899. Flora of the Caucasus. Tiflis. 584 p. [In Russian]

Litvinskaya S.A. 2004. Vegetation of the Black Sea coast of Russia (Mediterranean enclave). Krasnodar. 130 p. [In Russian]

Litvinskaya S.A. (Ed.). 2017. Red Data Book of the Krasnodarsky Krai. Plants and fungi. $3^{\text {rd }}$ ed. Krasnodar. 850 p. [In Russian]

Litvinskaya S.A. 2019. Taxonomic and biogeographic characteristics of the flora of the Western Ciscaucasus and Western Caucasus: Phylum Magnoliophyta: Classis Liliopsida. Vol. 2(1). Moscow. 560 p.

Makarova E.L., Shulakov A.A. 2011. Comperia comperiana (Stev.) Aschers. et Graebn. (Orchidaceae) a new species for the natural flora of Russia and the Caucasus. In: Protection and cultivation of orchids. Moscow: KMK Scientific Press Ltd. P. 286-289. [In Russian]

Maleev V.P. 1931. The vegetation of the Novorossiysk Mikhailovsky pass area and its relation to Crimea. Notes of the State Nikitsky Experimental Botanical Garden 13(2): 71-174. [In Russian]

Menitsky Yu.L. 1991. Project «Synopsis of Caucasus Flora». Map of Flora. Botanicheskii Zhurnal 76(11): 1513-1521. [In Russian]

Murtazaliev R.A. 2009. Orchidaceae. In: R.V. Kamelin (Ed.): Synopsis of the flora of Dagestan. Vol. 4. Makhachkala: Epokha. P. 16-28. [In Russian]

Nevski S.A. 1935. Orchidaceae. In: V.L. Komarov (Ed.): Flora of the USSR. Vol. 4. Leningrad: AS USSR. P. 589-730. [In Russian] 
Perebora E.A. 2011. Ecology of orchids of the North-Western Caucasus. Krasnodar: Kuban State Agrarian University. 441 p. [In Russian]

Plantarium. 2020. Open on-line atlas and key to plants and lichens of Russia and neighbouring countries. Available from http://www.plantarium.ru/ [In Russian]

Popovich A.V. 2013. New and rare species of vascular plants of the Novorossyisk floristical region (the Northwest Caucasus). Bulletin MSRU. Series: Geographical Environment and Living Systems 2: 70-75. [In Russian]

Popovich A.V. 2018. Rare species of vascular plants, entomofauna and herpetofauna of the tract «Myskhako». In: L.M. Shagarov (Ed.): Sustainable development of Protected Areas. Vol. 5. Sochi: Natural ornithological park in the Imeretinskaya lowland. P. 243-266. [In Russian]

Popovich A.V. 2019a. Rare plant species of the Novorossiysk floristic district and issues of their protection. $\mathrm{PhD}$ Thesis. Moscow. 603 p. [In Russian]

Popovich A.V. 2019b. On the need to protect the habitats of rare species of vascular plants on the cape Tonkiy (Gelendzhik). In: L.M. Shagarov (Ed.): Sustainable development of Protected Areas. Vol. 6. Sochi: Natural ornithological park in the Imeretinskaya lowland. P. 249-258. [In Russian]

Red Data Book of Russian Federation (plants and fungi). Moscow: KMK Scientific Press Ltd., 2008. 855 p. [In Russian]

Semagina R.N. 1999. Flora of the Caucasian State Biosphere Reserve. Sochi. 228 p. [In Russian]

Schiffers E.V. 1953. Vegetation of the North Caucasus and its natural forage land. Moscow; Leningrad. 400 p. [In Russian]

Shilnikov D.S. 2010. Orchidaceae. In: Synopsis of the flora of Karachay-Cherkessia: a monograph. Stavropol: AGRUS. P. 285-290. [In Russian]

Sramkó G., Óvári M., Yena A.V., Sennikov A.N., Somlyay L., Bateman R.M., Molnár A.V. 2012. Unravelling a century of misuse: typification of the name Himantoglossum caprinum (Orchidaceae: Orchideae). Phytotaxa 66: 21-26. DOI: $10.11646 /$ phytotaxa.66.1.4

Solodko A.S. 1999. To the geobotanical zoning of the Sochi Black Sea coast. Botanicheskii Zhurnal 84(1): 45-56. [In Russian]

Solodko A.S., Makarova E.L. 2011. Orchids of the Sochi Black Sea Region. Sochi. 48 p. [In Russian]

Solodko A.S., Nagalevsky M.V., Kiriy P.V. 2006. Atlas of the Sochi Black Sea Flora. Wild vascular plants. Sochi. 287 p. [In Russian]

Soltani G.A. 2015. Caucasian species of orchids in the Sochi Arboretum. In: L.M. Shagarov (Ed.): Sustainable development of Protected Areas. Vol. 3. Sochi: Natural ornithological park in the Imeretinskaya lowland. P. 330 333. [In Russian]

Suslova E.G., Kozhin M.N., Seregin A.P. 2015. List of vascular plants of the Abrau peninsula (from Sukko to Yuzhnaya Ozereyevka). In: Summer practice on biogeography in the
Western Caucasus: study guide. Moscow: Publishing House of Moscow State University. P. 112-209. [In Russian]

Timukhin I.N. 2002. Orchids of the foothill zone of the Black Sea coast of the Krasnodarsky Kray (Arkhipo-Osipovka - Psou). In: Problems of sustainable development of regions of recreational specialization. Sochi. P. 100-103. [In Russian]

Timukhin I.N. 2003. Orchids of the Caucasian State Nature Reserve. In: 80 years of the Caucasian State Nature Reserve - the path from the Grand Duke Hunt to the World Natural Heritage. Sochi: Prospect. P. 147-172. [In Russian]

Timukhin I.N. 2010. Natural hybdrids of the genus Orchis (Orchidaceae) representatives in Tuapse-Adler floristic district of the Western Transcaaucasia. Botanicheskii Zhurnal 95(2): 187-190. [In Russian]

Timukhin I.N. 2017. Threatened and endangered species of vascular plants in the Utrish State Nature Reserve: chorology and current number. In: Terrestrial ecosystems and adjacent marine ecosystems of the Abrau Peninsula: structure, biodiversity and conservation. Vol. 4. Moscow. P. 85-120. [In Russian]

Timukhin I.N., Tuniyev B.S. 2018. Atlas of rare species of plants of the Sochi National Park and Sochi Black Sea coast. Proceedings of the Sochi National Park 11: 1-522. [In Russian]

Vakhrameeva M.G., Varlygina T.I., Tatarenko I.V. 2014. Orchids of Russia (biology, ecology and protection). Moscow: KMK Scientific Press Ltd. 437 p. [In Russian]

Vereecken N.J., Dafni A., Cozzolino S. 2010. Pollination syndromes in Mediterranean orchids - implications for speciation, taxonomy and conservation. Botanical Review 76(2): 220-240. DOI: 10.1007/s12229-010-9049-5

Willis K.J. 2017. State of the world's plants report-2017. Kew: Royal Botanic Gardens. 97 p.

Yena A.V. 2012. Spontaneous Flora of the Crimean Peninsula. Simferopol: N.Orianda. 232 p. [In Russian]

Zernov A.S. 2000. Plants of the Northwestern Transcaucasus. Moscow: Moscow State Pedagogical University. 130 p. [In Russian]

Zernov A.S. 2006. Flora of the Northwest Caucasus. Moscow: KMK Scientific Press Ltd. 664 p. [In Russian]

Zernov A.S. 2013. Illustrated flora of the Southern stretch of the Russian Black Sea coast. Moscow: KMK Scientific Press Ltd. 588 p. [In Russian]

Zernov A.S., Alekseev Yu.E., Onipchenko V.G. 2015. Determinant key of vascular plants of the Karachay-Cherkess Republic. Moscow: KMK Scientific Press Ltd. 459 p. [In Russian]

Zhou T., Jin X.H. 2018. Molecular systematics and the evolution of mycoheterotrophy of tribe Neottieae (Orchidaceae, Epidendroideae). In: X.H. Jin, Y.M. Shui, Y.H. Tan, M. Kang (Eds.): Plant diversity in Southeast Asia. PhytoKeys 94: 39-49. DOI: 10.3897/phytokeys.94.21346 
ОРХИДЕИ ЧЕРНОМОРСКОГО ПОБЕРЕЖЬЯ КРАСНОДАРСКОГО КРАЯ (РОССИЯ): СОВРЕМЕННОЕ СОСТОЯНИЕ, НОВЫЕ НАХОДКИ, ОХРАНА

\author{
А. В. Попович 1 , Е. А. Аверьянова ${ }^{2}$, Л. М. Шагаров ${ }^{2,3}$ \\ ${ }^{1}$ Краснодарское региональное отделение Русского географического общества, Россия \\ e-mail: popovitch.antonio220386@yandex.ru \\ ${ }^{2}$ Российский университет дружбы народов, Россия \\ e-mail:drjoma2zimovnikova@gmail.com \\ ${ }^{3}$ Институт природно-технических систем, Россия \\ e-mail:lev049@mail.ru
}

\begin{abstract}
В статье приводится актуальный номенклатурный список таксонов семейства Orchidaceae Черноморского побережья Краснодарского края, с уточнением их таксономического статуса. На исследуемой территории нам достоверно известны местонахождения 51 таксона (41 вида и 11 подвидов), а также 10 гибридов. Из них пять таксонов не встречаются больше нигде в России: Cephalanthera epipactoides, Epipactis euxina (узкоареальный эндемик), E. leptochila subsp. neglecta, E. pontica, Serapias orientalis subsp. feldwegiana. Два таксона незначительно выходят за границы исследуемой территории: Epipactis condensata и Ophrys mammosa subsp. caucasica. Приведены сведения о гибридных таксонах орхидей. Для каждого таксона даны сведения по распространению, встречаемости и приуроченности к фитоценозам. Большинство таксонов в той или иной степени представлены в лесных сообществах. Только восемь видов, приурочены к травяным сообществам и экотоным местообитаниям. Девятнадцать таксонов находят благоприятные условия существования в антропогенно нарушенных местообитаниях, предпочитая просеки под опорами ЛЭП, обочины лесных дорог, залежи, сенокосные луга и даже дендропарки. Представлены данные о новых местонахождениях и сведения о состоянии находящихся в критическом состоянии и исчезающих видов орхидей Черноморского побережья Краснодарского края. Три вида, Anacamptis coriophora, Dactylorhiza incarnata и Epipactis palustris, исчезли с исследуемой территории, возможно, этому способствовала человеческая деятельность. Состояние региональных популяций десяти таксонов вызывает опасения их сохранения на територии Черноморского побережья Краснодарского края. Семь таксонов находятся критическом состоянии: Anacamptis laxiflora subsp. dielsiana, Cephalanthera epipactoides, Dactylorhiza viridis, Epipactis condensata, E. euxina, Neotinea ustulata, Ophrys apifera и Himantoglossum comperianum. Риск исчезновения этих видов с территории исследования очень высок. Еще 3 таксона можно охарактеризовать, как исчезающие виды: Himantoglossum caprinum, Ophrys mammosa subsp. caucasica, Orchis militaris subsp. stevenii. Обозначены проблемы сохранения видового разнообразия орхидей на исследуемой территории. Авторы убеждены, что наиболее эффективным методом охраны орхидей на Черноморском побережье Краснодарского края является дальнейшее развитие сети ООПТ, прежде всего за счет создания региональных ООПТ - природных парков и памятников природы, а также ООПТ местного значения.
\end{abstract}

Ключевые слова: Orchidaceae, Кавказ, категория Красного списка МСОП, Красная книга, особо охраняемая природная территория, охрана природы, редкий вид, список таксонов 